\title{
Health implications of engineered nanomaterials
}

\author{
Antonio Pietroiusti* \\ Received 8th November 2011, Accepted 5th December 2011 \\ DOI: 10.1039/c2nr11688j
}

With the development of nanotechnology, a growing number of people are expected to be exposed to its products, the engineered nanomaterials (ENMs). Some physico-chemical properties of ENMs, linked to their size in the nanoscale $(1-100 \mathrm{~nm})$, make them potentially more reactive, and therefore raise concern about possible adverse effects in humans. In this article, I discuss human diseases which may be predicted after exposure to ENMs, and how their pathogenetic mechanisms may be linked to exposure; in this regard, special emphasis has been given to the triad of oxidative stress/inflammation/genotoxicity and to the interaction of ENMs/proteins in different biological compartments. The analysis of possible adverse effects has been made on an organ-by-organ basis, starting from the skin, respiratory system and gastrointestinal tract. These sites are in fact not only those exposed to the highest amounts of ENMs, but are also the portals of entry to internal organs for possible systemic effects. Although the list and the relevance of possible human disorders linked to ENM exposure are at least as impressive as that of their direct or indirect beneficial effects for human health, we must be clear that ENM-linked diseases belong to the realm of possible risk (i.e. cannot be excluded, but are unlikely), whereas ENMs with proven beneficial effects are on the market. Therefore, the mandatory awareness about possible adverse effects of ENMs should in no way be interpreted as a motivation to disregard the great opportunity represented by nanotechnology.

Department of Biopathology, Tor Vergata University, Rome, Italy. E-mail: pietroiusti@med.uniroma2.it

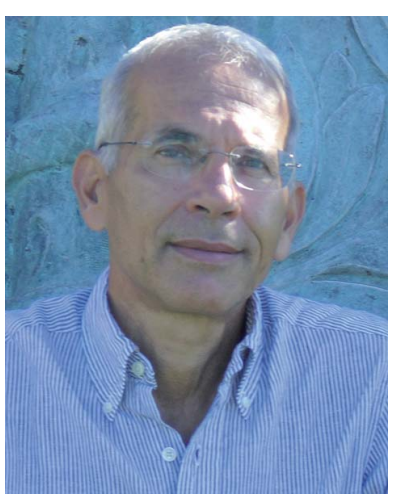

Antonio Pietroiusti

Antonio Pietroiusti is assistant Professor of Occupational Medicine at the Faculty of Medicine of Tor Vergata University, Rome, Italy. He is also Professor of Occupational Medicine at the Faculty of Odontostomatology of the same institution and adjunct professor at the Faculties of Medicine and Odontostomatology of the University "Nostra Signora del Buon Consiglio" of Tirana, Albania. He teaches Occupational Medicine at the Specialization School of Internal Medicine of Tor Vergata University. Dr Pietroiusti received his $M D$ degree and specialization in Internal Medicine from Tor Vergata University. He is currently involved in the research on embryotoxic effects of engineered nanomaterials.

\section{Introduction}

Nanomaterials (NMs), characterized by having at least one dimension $<100$ nanometres, are not a new entity: humans have been exposed to NMs generated by natural phenomena like volcanic eruptions and forest fires since their appearance on the Earth, and workers have been exposed for many decades both to NMs unintentionally produced by traditional occupational activities and to purposefully produced NMs like carbon black; in addition, episodic high level exposure to NMs contained in air pollution is experienced by people living in urban areas. However, until recently the risk of possible health problems related to this specific type of exposure was not appreciated. The recent understanding that NMs have new or enhanced properties in comparison to traditional materials has led to the development of nanotechnology, by means of which NMs with controlled physico-chemical characteristics are intentionally produced for novel industrial applications (engineered nanomaterialsENMs). This means that the degree of exposure to NMs and the percentage of exposed people will grow in the next few years, ${ }^{1}$ with time, the cumulative exposure will also unavoidably increase. Although these three conditions might be per se sufficient to raise attention on possible adverse health effects, the most compelling reason is that some ENM properties advantageous for industrial applications might be detrimental both for biological systems and the environment. This fact has led to the development of nanotoxicology ${ }^{2}$ i.e. the systematic evaluation of 
possible toxic effects elicited by nanotechnology products on cells or biological fluids (in vitro experiments) and animals (in vivo experiments). Data on humans are still lacking, except for isolated case-reports regarding accidental high dose exposure in the workplace; ${ }^{3-5}$ however experimental data obtained during the last decade may now allow one to make inferences about plausible human diseases and on appropriate safety measures for their prevention. Some insight may also come from epidemiological data regarding occupational exposure to unintentional NMs or environmental exposure to NMs present in air pollution.

On a short/mid-term perspective, the main groups at risk for exposure to ENMs are workers and consumers. As large amounts of these materials go through their life-cycle-from development, to manufacture, to consumer usage, to final disposal-also animal species (e.g. worm, fish) and natural environments (air, soil, sediment, water) will be substantially exposed to them, and secondary exposure of the general population might occur in the long term. However, any inference on possible human adverse effects due to secondary exposure would be highly speculative at this time, and will not therefore be discussed.

The main distinctive features of worker-relevant ENMs (WRENMs) and consumer-relevant ENMs (CR-ENMs) are shown in Table 1.

Workers clearly represent the group carrying the highest risk (they may be exposed also as consumers), but hyper-susceptible populations (extreme ages, people with chronic degenerative diseases) are certainly more represented among consumers. The two groups also partly differ for the main portal of entry (the gastrointestinal-GI-tract is relevant for consumers and negligible for workers), and for the specific ENMs to which they may be exposed (see below).

In this feature article, I will firstly describe the most important intrinsic characteristics of ENMs linked to pathogenetic mechanisms and the specific risks for workers and consumers. A systematic organ-by-organ approach, linking alterations detected in in vivo experiments (I will refer to in vitro data mainly to clarify pathogenetic mechanisms) with human disorders will thereafter be presented. In the last section, a balance between adverse and beneficial health effects in humans will be presented.

Table 1 Comparing worker-relevant engineered nanomaterials (WRENMs) and consumer-relevant engineered nanomaterials (CR-ENMs)

\begin{tabular}{|c|c|c|}
\hline & WR-ENMs & CR-ENMs \\
\hline \multicolumn{3}{|l|}{ Characteristic } \\
\hline Target & Workers & Consumers \\
\hline Main exposed organ & Lung and skin & $\begin{array}{l}\text { Lung, skin and } \\
\text { gastro-intestinal } \\
\text { tract }\end{array}$ \\
\hline Pattern of exposure & $\begin{array}{l}\text { Constant, low grade. } \\
\text { Potential for acute, } \\
\text { very high exposure in } \\
\text { the case of accident }\end{array}$ & $\begin{array}{l}\text { Unpredictable, } \\
\text { acute high exposure } \\
\text { unlikely }\end{array}$ \\
\hline $\begin{array}{l}\text { Prevalence of } \\
\text { hypersusceptible people }\end{array}$ & Low & $\begin{array}{l}\text { Potentially } \\
\text { substantial }\end{array}$ \\
\hline Awareness of exposure & $\begin{array}{l}\text { Easy to be } \\
\text { implemented }\end{array}$ & May be problematic \\
\hline Protection & Probably feasible & May be problematic \\
\hline
\end{tabular}

\section{ENM intrinsic properties linked with potential adverse effects}

When describing the biologic effects of ENMs, it is useful to distinguish between size-related properties, not shared by the bulk form, and nonsize-related effects, which may be exerted also by the bulk form.

\subsection{Size-related effects}

Size-related biologic effects are shown by ENMs, but not by the bulk form of the same material (or are shown at a much lower extent). The most relevant size-related properties of ENMs linked to biological activity are: the high ratio of particle number/ mass or surface area/mass, the tendency to aggregate/agglomerate in air or liquid, the increased reactivity of the atoms on their surfaces (these atoms are not bonded on side, in comparison to bonded atoms residing inside), protein/lipid absorption in vitro and in vivo, translocation to secondary target organs, poor clearance by macrophages, the ability to be transported through the axons of sensory neurons, and access to intracellular structures such as mitochondria and nuclei. ${ }^{6}$ There is consensus that some of these properties may cause dangerous effects in humans: for example, the high ratio of particle number/mass implies an increase of the contact area with biological surfaces: the increased contact area, associated with hyper-reactivity of surface atoms, is expected to amplify the possible damaging effect in comparison to the bulk form. This expectation is supported by a lot of experiments in different conditions showing that ENMs are more toxic than the bulk form. ${ }^{7-12}$

The equation lower size $=$ higher biologic effect may be true also in the nanoscale range and a critical threshold has been proposed at $30 \mathrm{~nm}$ : under this size, ENMs may obey quantum physics law instead of classical physics and in response may exhibit unique optical, magnetic and electrical properties; ${ }^{13}$ biological activity of some metallic ENMs seems to be enhanced under this threshold. ${ }^{14}$

Agglomeration and aggregation are size-related properties of some ENMs. Agglomeration is due to adhesion of particles to each other by weak forces, for example van der Waals forces, or to simple physical entanglement. In contrast, the forces holding an aggregate together are strong forces, for example covalent bonds, or those resulting from sintering or complex physical entanglement. Aggregation or agglomeration state could influence the deposition, the toxicokinetics, and the local toxicity of ENMs, due to significant variations in the aerodynamic radius and the total surface area. ${ }^{13,15}$ However, whether the degree of toxicity associated with self-assembled ENMs is quantitatively different than that induced by single ENMs is probably related to the specific type of ENM. ${ }^{16,17}$

The size-related characteristics of absorption, translocation to secondary target organs, poor clearance by macrophages, and access to intracellular structures will be extensively discussed in other sections of this article.

\subsection{Nonsize-related effects}

Nonsize-related characteristics of ENMs, which are nevertheless relevant for their biologic activity, are shape, charge, and 
stability. As far as the role of shape is concerned, it is exemplified by the comparison between the high aspect ratio nanomaterial (HARN) and low aspect ratio nanomaterial (LARN). HARNs seem to have a higher potential for harmful pulmonary effects, especially when they satisfy the so-called fibers paradigm, according to which a material with a length of $>20 \mu \mathrm{m}$ and a diameter of $<3 \mu \mathrm{m}$ has a peculiar pathogenic potential as in the case of asbestos. ${ }^{18}$ Some carbon nanotubes (CNTs) have a fiberlike shape, ${ }^{19,20}$ and are therefore of particular concern for possible asbestos-like effects, including pleural mesothelioma (see below).

There is evidence that charge may be also relevant for toxicity. In fact, both positively ${ }^{21}$ and negatively charged $\mathrm{ENMs}^{22}$ have been found to be more injurious to cells than noncharged ones. In general, it is believed that cationic surfaces are more toxic than anionic surfaces due to the affinity of cationic particles to the negative phospholipid head groups on protein domains on cell membranes; ${ }^{23,24}$ however, in some studies negatively charged ENMs tested more reactive than positively charged ones. ${ }^{25}$ It is therefore possible that the effect of charge depends on the specific ENM and experimental condition.

Stability includes two ENM properties: biopersistence (i.e. the extent to which ENMs remain in an organism/organ retaining their structure) and the tendency to leach components. Both properties may be linked to toxicity. Although in the absence of chronic studies there is incomplete information on biopersistence of ENMs in humans, it is highly probable that the slow clearance of low-soluble ENMs (e.g., CNTs or $\mathrm{TiO}_{2}$ ) may lead to accumulation over time eliciting a foreign body reaction, a chronic inflammatory process promoting damage to cells. On the other hand, the tendency of some ENMs to release over time components in the biological environment may be in some instances truely responsible for ENM-mediated toxic events, especially in the case of metallic nanoparticles..$^{12,26}$

Other nonsize-dependent ENM properties linked to biologic effects are surface coating and internal structure. Intentional surface coating generally aims to mitigate or eliminate the adverse effects of ENMs, and is therefore used for ENMs designed for biomedical purposes. Polyethylene glycol (PEG) is a biocompatible polymer extensively used for this purpose. As far as internal structure is concerned, Jiang et al. ${ }^{27}$ and Sayes et al. ${ }^{28}$ have shown that anatase $\mathrm{TiO}_{2}$ may be more toxic than the rutile form of the material.

\section{Pathogenetic mechanisms}

The most relevant pathogenetic pathway linking ENM exposure to tissue damage is represented by oxidative stress, ${ }^{29}$ a term used to describe an imbalance between the generation of reactive oxygen species (ROS) and the cells' ability to manage these oxidants. Although moderate levels of ROS are physiologically necessary, playing a role in gene expression, proliferative response and signal transduction, ${ }^{30}$ their excessive production causes damage to cellular components including proteins, lipids and DNA, induces pro-inflammatory signalling cascades, and ultimately leads to programmed cell death (apoptosis). ${ }^{31}$ ROS may be generated as a result of ENM-cell interactions, or even by ENMs themselves in the absence of such interactions (Fenton reaction) ${ }^{32}$ The most relevant cells in this process are monocytes and macrophages. Macrophages have several relevant functions: they are scavengers (able to phagocytose and degrade foreign material, including microorganisms), effectors of inflammation (both in the destructive and in the repair phases) and also antigen-presenting cells. The term macrophage is usually adopted for tissue resident or stimulus-recruited cells, while the term monocyte designates the "immature" blood form. These cells are particularly active at producing free radicals as part of their microbicidal arsenal and so their response to ENMs can contribute considerably to oxidative stress. The activation of redox sensitive transcription factors such as NF- $\kappa \mathrm{B}$ leads to transcription of pro-inflammatory genes inducing the production of inflammatory mediators such as cytokines, chemokines and adhesion molecules. ${ }^{33}$ These mediators in turn amplify the release of ROS by cells leading to a vicious cycle of further inflammation.

The oxidant stress paradigm does not necessarily apply to CNTs, at least as far as pulmonary response is concerned. ${ }^{34,35}$ For these ENMs the particle shape or aspect ratio appears to drive bioactivity.

Another important pathogenetic mechanism is represented by the interaction of ENMs with body proteins. Given its special relevance, this topic is discussed here in more detail.

\subsection{The nano-bio interface}

An extremely relevant process, elucidated in the last few years, is the interaction of ENMs with molecules present in biological fluids (mainly proteins), leading to a nano-bio interface. This interface, made mainly of proteins in the systemic circulation and of phospholipids in the lung, ${ }^{21,36}$ is not a static process, being characterized by continuous association and dissociation events that at a certain point reach an equilibrium. ${ }^{37}$ The final composition of the external coating, named protein corona, is determined by the ENM size and surface properties and by protein-protein interaction. ${ }^{38}$ According to size and surface properties, different types of protein corona and different temporal patterns of protein corona formation are detectable in ENMs having the same chemical composition. ${ }^{39,40}$ The final corona (hard corona) is long-lived and able to govern the particles biological fate, but will be modified when ENMs move from one biological compartment to another. ${ }^{41,42}$ Nevertheless, it maintains a fingerprint of the previous stay at another biological site, ${ }^{43}$ making thus possible to gain insights on the ENMs fate and behaviour in the human body from the analysis of the constituents of the protein corona. This fact may be of great relevance in the design of ENMs for biomedical purposes.

The corona has a great biologic relevance, since cells will in practice not be exposed to a "naked" nanoparticle - as technically produced-but rather to a nanoparticle-protein complex, with profound consequences both for the properties of the nanomaterials and for the cellular responses towards them. For example, the external protein coat initiates the mechanisms of recognition and internalization of ENMs by cells of the reticuloendothelial system (RES), ${ }^{21,36}$ causing their entrapment in organs such as liver and spleen, ${ }^{4-46}$ with a high content of RES cells. Nanostructures coated with polyethylene glycol or with ammonium/chelator functional group can avoid RES uptake, however. ${ }^{47}$ Proteins bound to nanoparticles may be perceived by 
dendritic cells (a class of cells specialised in sensing non-self entities such as microorganisms and particles, and in consequent antigen presentation) in a form and possibly also a shape that differs from those of proteins in solution. As an example, it has been recently shown that fibrinogen, when bound to negatively charged poly(acrylic acid)-conjugated gold nanoparticles, becomes partially unfolded and interacts in this form with the integrin receptor Mac-1, which mediates pro-inflammatory signals. ${ }^{48}$ Other findings suggest that ENMs such as $\mathrm{CNTs}, \mathrm{TiO}_{2}$, copolymer, cerium oxide $\left(\mathrm{CeO}_{2}\right)$, and quantum dots (QDs) have the potential to enhance protein assembly into amyloid fibrils by decreasing the lag time for nucleation: ${ }^{49,50}$ this process may have relevance for the pathogenesis of several human disorders (see below).

On the other hand, interaction of ENMs with body proteins may be advantageous for diagnostic and therapeutic purposes. For example, the interaction of nanocarrier systems with plasmatic apolipoprotein E, a brain transporter, may be crucial for the brain delivery of blood-brain-barrier-impermeable probes for optic and magnetic resonance imaging. ${ }^{51}$

\section{People at risk and hazard assessment at work}

\subsection{Workers}

Nowadays, ENMs can be found in a wide variety of products like electronics, automotives, health and fitness, food and beverages, goods for children and many other product categories as indicated by the commercialization of more than 1300 products, with a fivefold increase since March 2006 (www.nanotechproject.org). Some estimations predict that by 2015 at least 2 million workers will be employed in nanotechnology activities and that nanomaterials will be incorporated into $15 \%$ of global manufacturing output. ${ }^{1}$ Although, due to the current economic crisis and reduced sales (in e.g. cars, building materials and electronics), the estimations for the near future might be too high, their expected impact remains relevant and concerns about safe use of ENMs and possible consequences on human health and the environment are justified. These concerns are reinforced by recently reported serious adverse outcomes, including death, after accidental exposure to manufactured nanomaterial at work..$^{3-5,52}$

Very recently, the EU Commission recommended to consider nanomaterials as "natural, incidental or manufactured material containing particles, in an unbound state or as an aggregate or as an agglomerate and where, for $50 \%$ or more of the particles in the number size distribution, one or more external dimensions is in the size range $1 \mathrm{~nm}-100 \mathrm{~nm}$ ". ${ }^{53}$ This implies that the mere presence of NMs in a given work environment does not automatically determine exposure. However, whether this is true also for health effects is still unclear. ${ }^{53}$

In order to coordinate activities concerning safety assessment across industries and nations, the Organization for Economic Cooperation and Development (OECD) established in 2006 a Working Party on Manufactured Nanomaterials (WPMN) ${ }^{54}$ aimed, among the others, to develop and test a representative set of manufactured nanomaterials in order to improve the understanding of the intrinsic properties that may be relevant for hazard assessment, and to develop practical experience and evidence on the applicability of current OECD Test Guidelines. ${ }^{55}$
The list of prioritized nanomaterials which are to be addressed includes: single-walled carbon nanotubes (SWCNTs), multiwalled carbon nanotubes (MWCNTs), Fullerene (C60), aluminium oxide $\left(\mathrm{Al}_{2} \mathrm{O}_{3}\right)$, dendrimers, $\mathrm{TiO}_{2}$, zinc oxide $(\mathrm{ZnO})$, $\mathrm{CeO}_{2}$, iron, silver, gold, layered silicates (nanoclays), and silicon dioxide $\left(\mathrm{SiO}_{2}\right)$. Only a fraction of this list has been checked in workplace surveys.

Although an increasing number of instruments for measuring $\mathrm{NM}$ exposure in the workplace are becoming available (an extensive review of available instrumentations can be found in a recent publication of the National Institute for Occupational Safety and Health-NIOSH - in collaboration with the Centers for Disease Control and Prevention-CDC-["Approaches to Safe Nanotechnology" http://www.cdc.gov/niosh/docs/2009$125 /]$ ), the assessment of occupational exposure is far from being considered reliable for reasons related to metrics (none of the three most widely used metrics - mass concentration, number concentration, and surface concentration - may be considered ideal, although the above reported EU recommendation emphasizes the relevance of number concentration ${ }^{53}$ ) and to the instruments themselves (none of the available instruments has the necessary requisites for occupational surveys: portability, low cost, simple management and accuracy). In addition, specific occupational exposure level (OEL) values for nanoparticles do not yet exist. In practice, the limit values for amorphous silica ${ }^{56}$ and silver ${ }^{57}$ are also applicable to their nanoforms, although for the reasons exposed above it is doubtful that OELs working for 'bulk' substances would be appropriate for ENMs. In 2011, NIOSH recommended an exposure limit for engineered nanoscale $\mathrm{TiO}_{2}$ of $0.3 \mathrm{mg} \mathrm{m}^{-3}$, as time-weighted average (TWA) concentrations for up to 10 hours per day during a 40 hour work week, ${ }^{58}$ and has classified the $\mathrm{TiO}_{2}$ nanoform as a potential occupational carcinogen.

Given the above described limitations, measurements in the occupational setting are aimed to identify possible sources of release of manufactured NMs and to evaluate whether engineered and administrative measures are successful in eliminating these sources. There is increasing consensus that the best strategy for reaching these goals is represented by the Nanoparticle Emission Assessment Technique (NEAT) developed by the NIOSH $^{59}$ and successfully applied in several workplaces. ${ }^{60}$ NEAT is a multi-step flexible strategy, whose starting information, obtained with portable, low cost instruments, is represented by the degree of probability (high or low) that ENM emission is present in a given occupational environment. Subsequent steps are dictated by the initial information and by the level of accuracy which is considered necessary in a given occupational context.

For risk and exposure control, available data seem to indicate that engineered protective measures may be effective, ${ }^{61,62}$ and that protective equipments like last generation nonwoven fabrics $^{63}$ and NIOSH-tested (N95, P100) and CE-compliant (FFP2, FFP3) respiratory filter masks ${ }^{64}$ are efficient in protecting skin and lung from ENM exposure.

\subsection{Consumers}

The potential health risks of consumer products containing nanomaterials depend on the possible hazards of the 
nanomaterials in these products and the probability of exposure, therefore information is needed on: (a) how many consumer products containing nanomaterials are on the market, (b) the amount and type of nanomaterials in these products, (c) how many consumers use products containing nanomaterials, and (d) the probability that nanomaterials included in a given product may gain access to the human body.

The consumer products containing CR-ENMs are shown in Table 2.

Among consumer products containing NMs, those having the most relevant market portion are catalytic converters, automotive components, coating and adhesives, computer hardware components, displays, recording media, packaging material, cleaning products and sun cosmetics. In the future, it is expected that additional products like light emitting diodes, isolation material, and sport equipment will have relevance. ${ }^{65}$ Among these, the highest amount of ENMs is present in coatings and adhesives in the form of polymer suspensions for the application, for example, in exterior paints, food packaging (nanoclays), and catalytic converters (alumina). It should be kept in mind, however, that the probability of exposure of the consumer cannot be inferred by the amount of ENMs present in a given product, but by many other characteristics: how the product is used, how are ENMs incorporated in the product, etc. Taking into account these variables, experts agree that the products posing the highest probability of exposure are sun cosmetics (ENMs: $\mathrm{ZnO}$ and $\mathrm{TiO}_{2}$ ), oral hygiene products (ENM: hydroxyapatite-HAP), health products (ENM: silver), fuel (ENM: $\mathrm{CeO}_{2}$ ), coating and adhesives (ENM: polymer), cleaning products (ENMs: $\mathrm{Al}_{2} \mathrm{O}_{3}, \mathrm{TiO}_{2}$, polyurethane, others) ${ }^{65}$ (Table 3).

Table 2 The consumer categories and subcategories containing consumer-relevant engineered nanomaterials (CR-ENMs) (RVIM Report 3403700001, 2009) ${ }^{65}$

\begin{tabular}{ll}
\hline Category & Subcategory \\
\hline Electronics and computer & Computer hardware \\
& Display \\
& Recording media \\
& Energy related (battery) \\
& Electronic parts \\
& Lighting \\
& Ink and paper \\
& Packaging \\
Household products and & Cleaning products \\
home improvement & Coatings \\
& Sun cosmetics \\
Personal care and cosmetics & Over the counter health products \\
& Oral hygiene \\
Motor vehicles & Catalytic converter \\
& Interior \\
& Fuel \\
Coating \\
Sporting goods & Lighting \\
Textile and shoes & Equipment \\
Filtration, Purification, & Textile coatings \\
Meutralisation, and Sanitisation & Coatings \\
& Professional clothing \\
& Other textiles \\
& Water filtration and purification \\
& Coatings and adhesives \\
& Isolation material \\
& \\
& \\
&
\end{tabular}

This journal is (C) The Royal Society of Chemistry 2012
Table 3 Products containing consumer-relevant nanomaterials (CRNMs) with high probability of coming in contact with consumers

\begin{tabular}{ll}
\hline Product & $\mathrm{CR}-\mathrm{NMs}$ \\
\hline Sun cosmetics & $\mathrm{ZnO}, \mathrm{TiO}_{2}$ \\
Oral hygiene & $\mathrm{Hydroxyapatite}$ \\
Over the counter health products & $\mathrm{Silver}$ \\
Fuel & $\mathrm{CeO}_{2}$ \\
Coatings and adhesives & $\mathrm{Polymer}$ \\
Cleaning products & $\mathrm{Al}_{2} \mathrm{O}_{3}, \mathrm{TiO}_{2}$, \\
& polyurethane, others
\end{tabular}

\section{Effects of ENMs on organs and organ systems}

The first organs and organ systems exposed to ENMs are the respiratory system, the skin, and the GI tract. ENMs may give local damage to these sites and/or may cross them gaining access to internal organs. Spherical and short fiber-shaped ENMs cross the epithelial pulmonary lining, reach the pleural space and thereafter, through the stomata, the mediastinal lymph nodes and the systemic circulation, ${ }^{20}$ a systemic diffusion of gold, silver, $\mathrm{ZnO}$ and $\mathrm{TiO}_{2}$ ENMs has been shown after oral administration, ${ }^{6-70}$ whereas current evidence suggests minimal penetration of ENMs in the skin. ${ }^{71}$

Consequences to distant sites may also result from indirect mechanisms, as in the case of neurological reflexes evoked by the presence of ENMs in the lungs, ${ }^{72}$ or in the case of systemic low grade chronic inflammatory state caused by persistent local inflammation. ${ }^{73}$ The indirect mechanism explains some effects on the cardiovascular system seen after pulmonary exposure to ENMs.

\subsection{Respiratory tract}

The respiratory tract is a relevant target for exposure to ENMs both from an occupational or consumer perspective. Damaging effects of ENMs are indirectly suggested by epidemiologic data in humans regarding exposure to incidental NMs in traditional work activities and to NMs present in air pollution. Short-term studies on air pollution health effects have shown a significant positive association between NM exposure and mortality, which was not present for micron-sized particles. ${ }^{74}$ In addition, some studies have shown that exposure to NMs present in air pollution may exacerbate pre-existing respiratory diseases. ${ }^{75,76}$ Very recently, an increased mortality due to chronic obstructive pulmonary disease (COPD) has been reported in a cohort of workers exposed to metalworking fluids containing a substantial amount of incidental NMs. ${ }^{77}$

ENMs deposit along the entire respiratory tract: ${ }^{78}$ however, local relevant effects have been described only in the very distal regions. These consist of pneumonia, fibrosis, granuloma formation, alveolar proteinosis, and pleural injury. Pleural effects have been included among the local effects, although, strictly speaking, ENMs must cross the alveolar barrier in order to reach the pleura. Concomitant local adverse effects have been often reported in the same animal.

(A) Pneumonia. Experimentally induced acute pulmonary inflammatory changes have been reported for some ENMs like $\mathrm{TiO}_{2}$, nickel oxide $(\mathrm{NiO}), \mathrm{CeO}_{2}, \mathrm{ZnO}$, and copper oxide 
$(\mathrm{CuO}){ }^{11,12}$ Comparative studies show that the inflammatory potential of $\mathrm{NiO}$ is much higher than that of $\mathrm{TiO}_{2},{ }^{79}$ and recent data suggest that the exposure to $\mathrm{TiO}_{2}$ at doses plausible for human exposure causes only mild, transient inflammation. ${ }^{80}$ By contrast, the inflammatory changes following pulmonary exposure to $\mathrm{NiO}$ seem to be persistent, both after a single instillation and in a chronic exposure model. ${ }^{81,82}$ Variable inflammatory responses, ranging from no response to high level inflammation, have been associated with pulmonary exposure to CNTs. A much more homogeneous pattern of fibrosis and/or granuloma formation has been reported for these ENMs, so pertinent data regarding inflammation will be reported when treating these pathologic changes.

(B) Fibrosis. Experimental animal studies support the fibrogenic effect of some ENMs. It generally follows pulmonary inflammation, which may be sustained, as in the case of fibrosis associated with $\mathrm{NiO}^{83}$ exposure, or mild and transient, as in the case of $\mathrm{ZnO}$ and $\mathrm{CuO}^{12,84}$ exposure. However, CNTs may induce fibrosis even in the absence of inflammation. ${ }^{15}$ In this latter case, the process seems to be linked with the ability of CNTs to directly stimulate proliferation of fibroblasts once they come in contact with these cells in the pulmonary interstitium. ${ }^{85} \mathrm{~A}$ similar property has not been shown until now for other ENMs. It should be noted, however, that pulmonary inflammation has been also reported in some instances of fibrosis linked to CNTs exposure. ${ }^{86}$ Therefore, CNTs may probably induce pulmonary fibrosis with more than one mechanism.

(C) Granuloma formation. The formation of pulmonary granulomas is typically associated with exposure to CNTs. They have been observed in virtually all published studies on pulmonary toxicity of single-wall carbon nanotubes (SWCNTs), and in some studies regarding multi-wall carbon nanotubes (MWCNTs). ${ }^{34,86-92}$ This response seems therefore to be CNT specific, having been reported both in different animal species, ${ }^{34,87-91}$ and after exposure to CNTs containing different amounts and types of metallic contaminants. ${ }^{34}$ Pulmonary alveolar macrophages represent the central cell type in this reaction, which has been hypothesized to be the consequence of their inability to engulf long CNT fibers (frustrated phagocytosis), thus leading to phagosomal destabilization and activation of the inflammasome ${ }^{93}$ However, there is no clear demonstration of this hypothesis. Mercer et al. ${ }^{94}$ have shown that pulmonary granulomas or pulmonary fibrosis outcomes depend on the degree of dispersion of CNTs: agglomerated CNTs induce more pulmonary granulomas, whereas diffuse fibrosis is the main pathologic event when the lungs are exposed to a well dispersed material. The presence of CNTs inside macrophages in the context of granulomas ${ }^{34}$ (i.e. in the absence of frustrated phagocytosis) seems to support this model.

As in the case of fibrosis, inflammatory changes may ${ }^{91}$ or may not ${ }^{92}$ be present.

(D) Alveolar lipoproteinosis. Alveolar lipoproteinosis has been found to be a long-term sequela after a single pulmonary exposure to $\mathrm{NiO}^{12}$ or to MWCNTs. ${ }^{95,96}$

(E) Pleural injury. Pleura are the layers that cover the lungs (visceral pleura) and inside of the chest wall (parietal pleura) such that the two pleura are opposite each other during normal breathing. The possible development of pleural pathologies obviously implicates delivery of ENMs into the pleural space, which is lined by cells named mesothelial cells. Although the exact mechanism is not fully understood, it has become clear that all ENMs that deposit in the periphery of the lung may translocate to some extent into the pleural space. ${ }^{18,97}$ However, whereas LARN and spherical ENMs are rapidly cleared from the pleural space through the pleural stomata (holes sizing about $10 \mu \mathrm{m}$, located in the parietal pleura), HARNs are not. ${ }^{20}$ The protracted interaction between the longer fibers and the mesothelial cells leads to chronic inflammatory state and fibrosis. ${ }^{20}$ The above described processes and pathologic changes have also been observed after exposure to asbestos fibers, the most dangerous fiber-shaped particles. ${ }^{98}$ The most feared effect of asbestos is represented by pleural mesothelioma, a cancer arising from mesothelial cells. Differently from most cancers, which are generally caused by several concomitant environmental factors, the only known environmental factor causing mesothelioma is asbestos. Although it has been reported that peritoneal mesothelial cells (which are very similar to pleural mesothelial cells) react to long MWCNTs and to long NiO fibers in a way similar to asbestos ${ }^{19,99}$ (but no mesothelioma has been reported in these experiments), studies targeting the relationship between CNT exposure and the development of mesothelioma did not yield univocal results. ${ }^{100,101}$

\subsection{Skin}

In spite of several in vitro studies showing toxic effects for fullerene, ${ }^{102}$ SWCNTs, ${ }^{103}$ MWCNTs,${ }^{104}$ QDs,${ }^{105}$ and $\mathrm{TiO}_{2},{ }^{106}$ very sparse data have been published on in vivo skin toxicity of ENMs. Available studies suggest inflammation, benign cutaneous tumours and granulomas as possible adverse outcomes.

(A) Inflammation. Topical exposure of SKH-1 mice (5 days, with daily doses of 40-160 microgram per mouse) to SWCNTs caused skin thickening associated with the infiltration of polymorphonuclear leukocytes (PMNs), which are cells associated with acute inflammation. ${ }^{107}$

(B) Benign cutaneous tumours. Long term repeated application of fullerenes to mouse skin in association with tumor initiators and promoters suggested a role of fullerene in the development of benign skin tumors. ${ }^{108}$

(C) Granulomas. Granulomas, similar to those observed in the lung, were seen 1 week after CNTs were implanted in the subcutaneous tissue of rats. Nanotubes were present in macrophages. ${ }^{109}$

\subsection{Gastrointestinal tract}

No reliable in vivo studies suggesting adverse effects of ENMs on the gastrointestinal tract are currently available. Research in this important area is urgently needed, given the relevance of this organ system for consumer exposure.

\subsection{The cardiovascular system}

The plausibility of adverse health effects of ENMs on the cardiovascular systems comes from the epidemiological, in vivo, 
in vitro and ex vivo studies showing that $\mathrm{NMs}$ are the most important components of the injury to the cardiovascular system related to air pollutants. ${ }^{110-112}$ An association with mortality due to ischemic heart disease (IHD) has been recently reported in a cohort of workers exposed to metalworking fluids containing a substantial amount of incidental $\mathrm{NMs},{ }^{77}$ although the strength of this association was weaker than that with COPD.

To date, there are no observational studies linking exposure to engineered nanomaterials and cardiovascular events, however a number of pre-clinical studies have reported that exposure to engineered nanomaterials, directly or indirectly, can cause cardiovascular injury. Available experimental evidence suggests that ENMs may represent risk factors for atherosclerosis, may induce the development, progression and destabilization of the atherosclerotic plaque, and may be the cause of cardiac arrhythmias.

(A) Potentiation of risk factors for atherosclerosis. ENMs may interact with two relevant risk factors for atherosclerosis: platelet aggregation and systemic inflammation. In fact, activation of human platelets has been reported after exposure to polystyrene latex nanoparticles and CNTs, ${ }^{113,114}$ and systemic inflammation has been induced by iron oxide $\left(\mathrm{Fe}_{2} \mathrm{O}_{3}\right)$ ENMs and CNTs. ${ }^{115,116}$ Long term systemic low-grade inflammation is nowdays considered the main determinant of atherosclerosis ${ }^{\mathbf{1 1 7}}$ and an increase in platelet aggregation is considered so dangerous that antiplatelet agents are included in strategies of primary prevention aimed to reduce the risk of cardiovascular disease in healthy people. ${ }^{118}$ Therefore, care is needed in exposed people with traditional risk factors for atherosclerosis.

(B) Progression of atherosclerosis. Available in vivo data show that $\mathrm{CNT}$ and $\mathrm{Fe}_{2} \mathrm{O}_{3}$ increase the expression of adhesion molecules in endothelial cells, ${ }^{115,116}$ and that $\mathrm{NiO}, \mathrm{TiO}_{2}$ and CNTs cause an accelerated progression of atherosclerotic plaque in susceptible animal models. ${ }^{90,119,120}$ In one experiment, the effect on plaque progression was observed only in association with a hyperlipidemic diet. ${ }^{90}$ In addition, rapid thrombus formation in damaged carotid arteries was observed in rats and mice after exposure to CNTs. ${ }^{113,121}$

(C) Cardiac arrhythmias. Two recent studies suggest that exposure to ENMs may alter the physiologic control of heart rate. In one animal study Legramante et al. ${ }^{122}$ showed in a rat model that pulmonary exposure to CNTs impairs the neurologic control of cardiac rhythm. In the second study, an adverse effect on cardiac rhythm induced by $\mathrm{TiO}_{2}$ and $\mathrm{SiO}_{2}$ was reported in an isolated beating heart model (Langendorff heart). ${ }^{123}$

(D) Impaired vasodilation. Endothelial vasodilator dysfunction may contribute to ischemic manifestations during times of increased oxygen demand. The phenomenon is particularly relevant in the case of coronary artery circulation, since it might cause myocardial angina. The findings of Nurkiewicz et al. ${ }^{124}$ and LeBlanc et al. ${ }^{125}$ showing that inhalation of nano- $\mathrm{TiO}_{2}$ decreases the ability of systemic and coronary arterioles to respond normally to vasodilators support this potential dangerous effect of ENMs.

\subsection{Central nervous system}

The neurological system is protected by the so-called blood brain barrier (BBB), which results primarily from the presence of tight junctions between the endothelial cells of the cerebral vessels. These tight junctions, which are not present in other vascular districts, strongly reduce the permeability to circulating substances. Given their very small size, ENMs may probably cross intact BBB, although at a low extent, ${ }^{\mathbf{1 2 6}}$ however they may reach the brain also through translocation along axons and dendrites of neurons., ${ }^{9,31}$ The following adverse effects of ENMs on the neurological system have been reported: disruption of $\mathrm{BBB}$ and inflammatory changes.

(A) Disruption of BBB. In vivo studies have shown the ability of $\mathrm{Cu}, \mathrm{Ag}$ and $\mathrm{Al}$ ENMs to increase the permeability of capillary endothelium and disrupt the normal function of the BBB. ${ }^{127-129}$ Generally, these ENMs are also able to induce direct damage to the cells of the central nervous system: therefore, once BBB integrity is compromised, the neurological damage may be further amplified. In addition, the damaged BBB allows the entry into the brain of activated immune cells, which may induce further inflammation.

(B) Inflammation. An increase in CNS inflammatory markers has been observed after intranasal exposure to $\mathrm{Mn}$ oxide (MnO) and Carbon black, ${ }^{130,131}$ and an enhancement of the response to inflammogenic stimuli has been reported after administration of $\mathrm{TiO}_{2} \mathrm{NMs}^{132}$ These findings are in agreement with data available for air-pollution related NMs. ${ }^{133,134}$

\subsection{Reproductive system}

Although the possible effects of ENMs on reproductive and developmental outcomes are of obvious clinical and social relevance, little research has been performed on this aspect of nanotoxicology, so very few data have been reported until now. Available information is of interest, however, since it suggests that adverse effects such as reduced fertility and developmental toxicity may occur. Of particular relevance are the data regarding the effects of in utero exposure.

Similarly to the case of CNS access, ENMs must cross a barrier, represented in this case by the placenta, in order to reach their target (the embryo). In this case, however, damage to the barrier causes immediate and profound effects on the embryo: in fact, the placenta represents the only way by which the embryo may obtain oxygen and nourishment. Not surprisingly, placental alterations are linked to embryo growth defects, even in the absence of direct exposure of the embryo. Several ENMs like $\mathrm{TiO}_{2},{ }^{135}$ fullerene, ${ }^{136}$ polystyrene, ${ }^{137}$ and silica ${ }^{138}$ may cross the placenta and some may cause placental damage. ${ }^{138,139}$

(A) Male and female fertility. A reduction in daily sperm production has been reported after carbon black administration. ${ }^{140} \mathrm{In}$ mice, either $\mathrm{ZnO}$ or composite carbon and $\mathrm{ZnO}$ ENMs intra-tracheally instilled during gestation decreased the rate of gestation. $^{141}$ 
(B) Embryotoxicity. Effects on embryo (prenatal effects) may be general or localized and may range from mild alterations such as reduced body weight or growth retardation to severe structural defects and death. Postnatal effects may also manifest as delayed physical development or specific organ defects or as functional deficits (e.g. impaired cognitive function) without obvious structural correlates. Increased propensity to develop allergy is another recognized postnatal effect.

Prenatal effects. A high rate of severe malformations and abortions has been recently reported in mice after in utero exposure to low dose $\mathrm{CNTs}^{139}$ (Fig. 1); severe malformations have also been reported after exposure to fullerene, but at very high doses. ${ }^{142}$ Milder effects on development were seen after exposure to silica and $\mathrm{TiO}_{2}$ ENMs. ${ }^{138}$

Postnatal effects. $\mathrm{TiO}_{2}$ ENM has been shown to affect adversely the fertility and cerebral functions of offspring, ${ }^{143-146}$ whereas carbon black exposure was associated with genetic lesions in the liver of offspring. ${ }^{147}$

Of note, the above reported embryotoxic effects have been detected with several different routes of exposure, and at quite different doses: intravenous exposure: $100 \mathrm{ng}$ per mouse of $\mathrm{CNTs}^{139}$ and $1.6 \mathrm{mg}$ per mouse of $\mathrm{TiO}_{2}$ and silica; ${ }^{138}$ intraperitoneal exposure: $25 \mathrm{mg} \mathrm{kg}^{-1}$ of fullerene; ${ }^{142}$ subcutaneous injections: $100 \mu \mathrm{g}$ per mouse ${ }^{143}$ to $400 \mu \mathrm{g}$ per mouse ${ }^{144}$ of $\mathrm{TiO}_{2}$; intratracheal instillation: cumulative doses of carbon black higher than $200 \mu \mathrm{g}$ per mouse, ${ }^{147}$ intra-gastric exposure: cumulative dose of 2 g per mouse, ${ }^{146}$ inhalation: $42 \mathrm{mg} \mathrm{m}^{-3} 1$ hour per day for 10 days. ${ }^{145}$

\section{Systemic effects}

In this section are included genotoxic and immunotoxic effects, given the fact that genetic and immune damage may have influence on any organ or organ system.

\subsection{Genotoxicity}

Genotoxicity concerns the chemical and physical perturbations in DNA following exposure to endogenous or exogenous agents. Nanomaterials may cause genotoxicity by means of direct interaction with DNA or by means of indirect mechanisms. Direct DNA damage can only be induced if the nanomaterials are able to penetrate the cell nucleus, or those free in the cytoplasm may have the opportunity to come into direct contact with DNA during cellular division when the nuclear membrane breaks down. Although there is suggestion that some ENMs like $\mathrm{TiO}_{2}, \mathrm{ZnO}$, QDs and silica may gain access to the nucleus, ${ }^{148-152}$ it is less clear if they are also able to cause DNA damage.

Indirect DNA damage is certainly more important for ENMs. It is determined by the interference of ENMs with biomolecules relevant for DNA replication, without a direct contact with DNA itself (mechanism 1), or by the induction of oxidative DNA lesions secondary to cellular oxidative stress (mechanism 2). ${ }^{153}$ There is evidence from in vitro studies that CNTs and silica may act by means of mechanism $1,{ }^{154,155}$ whereas genotoxicity induced by mechanism 2 has been reported in vivo for $\mathrm{TiO}_{2}$, fullerene,
CNTs, $\mathrm{Al}_{2} \mathrm{O}_{3}$, and carbon black. In detail, after oral administration, fullerene and CNTs induced genetic damage in rat liver and lung cells, ${ }^{156} \mathrm{TiO}_{2}$ in peripheral blood cells and bone marrow of adult mice and in the offspring of in utero exposed mice ${ }^{157}$ and $\mathrm{Al}_{2} \mathrm{O}_{3}$ in peripheral blood cells. ${ }^{158}$ Intratracheal exposure to carbon black induced genetic damage in the liver of pregnant mice. ${ }^{147}$

\subsection{Immunotoxicity}

There are good reasons to evaluate the immune system after exposure to ENMs. First of all, immune cells are very abundant in organs and organ systems firstly exposed to ENMs (i.e. skin, respiratory system and GI tract). Second, these cells play a crucial role in determining the outcome of ENM exposure: for example, elusion of phagocytosis may facilitate access to internal organs and the related untoward effects. Third, ENMs may cause immunosuppression or immunoactivation. It is well known that immunosuppression lowers the body's defence against, for example, infection and cancer, and some studies show that pulmonary exposure to CNTs suppresses lymphocyte $\mathrm{B}$ cell function (B lymphocytes are circulating cells involved in the production of antibodies against offending exogenous material); ${ }^{159}$ by contrast both fullerene ${ }^{160}$ and dendrimers ${ }^{161}$ may elicit ENM specific antibodies (i.e. they may cause immunoactivation). Another area regarding immunoactivation is the elicitation of allergic reactions: for example, CNTs and silica have been shown to enhance the allergic response to egg albumin in mice. ${ }^{162,163}$ The most important effect of ENMs on the immune system is however the elicitation of soluble immune hormones (cytokines, chemochines) in the context of inflammation, a property shared by almost all ENMs under appropriate conditions.

Finally, another way by which ENMs may affect the immune system function is through their well known interaction with body fluid components (in particular proteins), which has been treated in the section on nano-bio interface.

\section{Interpretation of available data and inference for human diseases}

Taken together, the above reported data, based on in vitro cell culture studies and in vivo animal studies, raise concern about possible toxicity in humans. However, the issue of ENM toxicity for humans remains controversial. The main factors limiting extrapolation to humans of available findings are:

1. To date, there is no conclusive evidence of a known human toxic response that is specifically caused by nanomaterials. Effects seen in animals cannot be automatically translated to humans.

2. Experimental conditions rarely mimic the expected exposure in humans. The main issues are represented by very high doses, given as a bolus, whereas chronic low-dose exposure is expected exposure in humans. Even in the case of hypothetical accidental exposure the doses used in experiments generally exceed those expected in humans.

3. Data are not univocal. Some well performed studies show no toxicity from the same nanomaterials showing adverse effects in other experiments. ${ }^{164,165}$ This is probably due to the lack of 

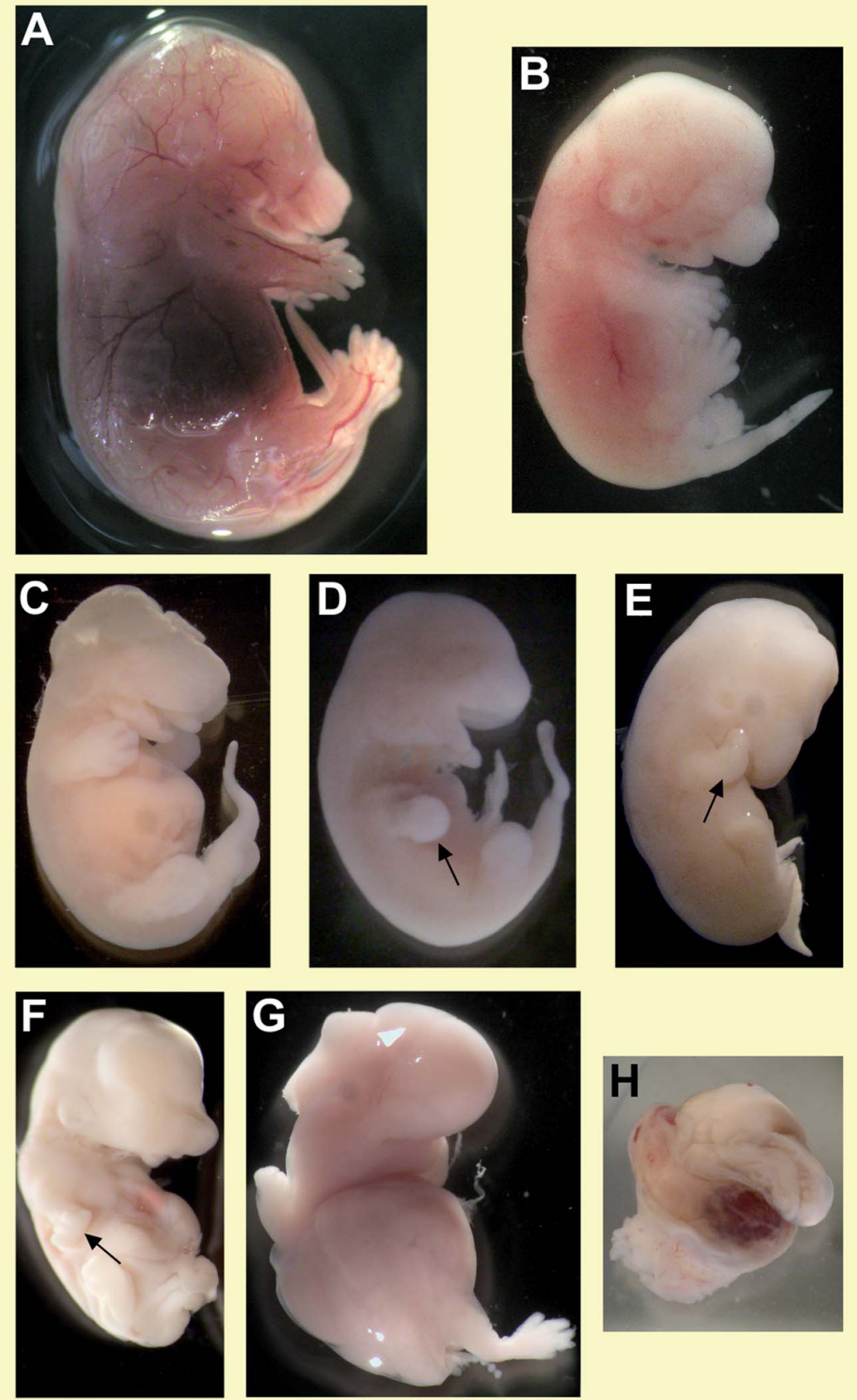

Fig. 1 Representative images of malformed mice embryos after maternal exposure to carbon nanotubes. Normal developed embryo is shown in panel A. Panels B to $\mathrm{H}$ show embryos of the same gestational age with developmental abnormalities of progressive severity, ranging from mild retardation to complete structural derangement. In panel D, E, and F arrows indicate incompletely developed limbs. (Adapted with permission from A. Pietroiusti, M. Massimiani, I. Fenoglio, M. Colonna, F. Valentini, G. Palleschi, A. Camaioni, A. Magrini, G. Siracusa, A. Bergamaschi, A. Sgambato, L. Campagnolo, ACS Nano, 2011, 5, 4624. Copyright 2011 American Chemical Society.)

standardization both in characterizing the nanomaterial and in the methods used to challenge the nanomaterials with biologic systems.

On the other hand, some facts should also be considered: in some studies, ENMs displayed the same toxic effects as particles known to be dangerous for humans in occupational or environmental settings. As an example, in several studies in which a direct comparison between CNTs and asbestos has been made, similar toxicity has been reported. ${ }^{19,88,100}$

There are very few data which may be extrapolated to potential hyper-susceptible groups (i.e. people with chronic diseases, in the extreme ages, pregnant women) although the most relevant health effects from ENM exposure may be expected in these populations. 
Another point is represented by the possibility that ENMs, albeit not toxic or mildly toxic by themselves, may make people prone to diseases caused by other agents: for example, Shvedova et al. have shown that pulmonary clearance of the bacterium Lysteria monocytogenes is altered after pulmonary exposure to CNTs. ${ }^{166}$ It probably depends on the fact that nanoparticleloaded immune cells may be less able to tackle incoming danger in an adequate fashion.

With these limitations in mind, some inference on human diseases representing potential priorities in future health surveillance programs can be made. These disorders are listed in Table 4. Some of these diseases are known to be linked to exposure to environmental or occupational agents (and therefore ENMs might represent further offending agents), whereas some others represent a general response to still unrecognized offending agents.

Clearly, the organ systems in which specific diseases seem more supported are the respiratory system and the cardiovascular system. It is suggestive that both systems have been shown to be affected in humans by work-related incidental NMs and by pollution-related NMs. ${ }^{7-77,110-112}$

\subsection{Human pleuro-pulmonary diseases}

As far as the respiratory system is concerned, the alterations observed in in vivo experiments are: acute inflammation, fibrosis, granulomas, alveolar lipoproteinosis, pleural fibrotic changes, and pleural mesothelioma. The acute inflammation experimentally seen with some ENMs may have in humans the clinical counterpart in the adult respiratory distress syndrome (ARDS), which is a multifactorial life-threatening disease characterized by acute inflammation. ${ }^{167}$ Interestingly, a case of adult respiratory distress syndrome following accidental occupational exposure to nickel ENMs (one ENM causing acute pulmonary inflammation in experimental conditions) has been reported. ${ }^{5}$ Fibrosis is another adverse effect observed in animal studies. It is a pathologic process characterised by the accumulation of collagen and fibronectin matrix, fibroblast proliferation and myofibroblast transformation. In humans, it is often associated with chronic pulmonary inflammation, but in some disorders, like idiopathic pulmonary fibrosis, it does not seem to be correlated with inflammation. ${ }^{168,169}$ This latter form resembles the effect observed after exposure to CNTs (Fig. 2).

Granulomas are found in several human disorders. They are a typical response to exogenous material which is not easily cleared by immune cells, and involve primarily the macrophages (foreign body reaction): the biopersistence of CNTs and their presence in the context of granulomas make this parallel appealing (Fig. 3).

Pulmonary granulomas are also typically seen in other disorders of uncertain etiology like sarcoidosis, and are also observed after occupational exposure to beryllium dust. ${ }^{170,171}$ Interestingly, pulmonary lesions associated with beryllium exposure seem to be caused by the nanometric component of the dust. ${ }^{172}$ Alveolar lipoproteinosis is a well known, albeit uncommon, severe lung disease in humans. It may be caused by bacterial or viral infection, or by inhalation of dust ${ }^{173,174}$ (Fig. 4).

Table 4 Human diseases potentially linked to ENMs exposure, on the basis of in vivo experimental data. Inference on diseases should be considered speculative at the current status of knowledge. More plausible ENMs and more plausible disease are written in bold characters

\begin{tabular}{|c|c|c|c|c|}
\hline $\begin{array}{l}\text { Organ/organ } \\
\text { system }\end{array}$ & $\begin{array}{l}\text { Pathologic findings in in vivo } \\
\text { studies }\end{array}$ & Exemplar ENMs & Potential human diseases & Ref. \\
\hline \multirow{6}{*}{$\begin{array}{l}\text { Respiratory } \\
\text { system }\end{array}$} & Acute inflammation & $\mathrm{TiO}_{2}, \mathbf{N i O}, \mathrm{CNTS}$ & Acute respiratory distress & $5,11,12,79-82$ and 167 \\
\hline & Fibrosis & $\mathrm{NiO}, \mathrm{ZnO}, \mathrm{CuO}, \mathrm{CNTs}$ & $\begin{array}{l}\text { Idiopathic pulmonary fibrosis, } \\
\text { asbestosis-like fibrosis }\end{array}$ & $12,15,83-86,168$ and 169 \\
\hline & Granulomas & CNTs & $\begin{array}{l}\text { Granulomatous lung disease, } \\
\text { berilliosis-like pulmonary } \\
\text { disease, sarcoidosis }\end{array}$ & $34,86-92$ and $170-172$ \\
\hline & Alveolar lipoproteinosis & $\mathrm{NiO}, \mathrm{CNTs}$ & Alveolar lipoproteinosis & $12,95,96,173$ and 174 \\
\hline & Pleural fibrotic changes & $\begin{array}{l}\text { High aspect ratio } \\
\text { nanomaterials (long CNTs, } \\
\text { long NiO) }\end{array}$ & Asbestos-like pleural fibrosis & 19,98 and 99 \\
\hline & Pleural Mesothelioma & $\begin{array}{l}\text { High aspect ratio } \\
\text { nanomaterials (long CNTs) }\end{array}$ & Pleural mesothelioma & 100 and 101 \\
\hline \multirow[t]{3}{*}{ Skin } & Acute inflammation & CNTS & Aspecific dermatitis & 107 \\
\hline & Benign tumours & Fullerene & Benign tumours & 108 \\
\hline & Subcutaneous granulomas & CNTs & Foreign body reaction & 109 \\
\hline \multirow[t]{3}{*}{$\begin{array}{l}\text { Cardiovascular } \\
\text { system }\end{array}$} & $\begin{array}{l}\text { Progression of established } \\
\text { atherosclerosis }\end{array}$ & $\mathrm{TiO}_{2}, \mathbf{N i O}, \mathbf{C N T S}, \mathbf{F e}_{2} \mathrm{O}_{3}$ & $\begin{array}{l}\text { Progression of atherosclerotic } \\
\text { plaque }\end{array}$ & $90,115,116,119$ and 120 \\
\hline & $\begin{array}{l}\text { Acute thrombosis of } \\
\text { damaged arteries }\end{array}$ & CNTs & $\begin{array}{l}\text { Myocardial infarction and } \\
\text { ischemic stroke }\end{array}$ & 77,113 and 121 \\
\hline & Arrhythmias & $\mathrm{TiO}_{2}, \mathrm{SiO}_{2}, \mathrm{CNTs}$ & Sudden cardiac death & $111,122,123$ and 175 \\
\hline \multirow[t]{2}{*}{$\begin{array}{l}\text { Central nervous } \\
\text { system }\end{array}$} & $\begin{array}{l}\text { Disruption of blood-brain } \\
\text { barrier }\end{array}$ & $\mathrm{Al}, \mathrm{Cu}$ and $\mathrm{Ag}$ ENMs & Multiple sclerosis & $127-129$ and 176 \\
\hline & Aspecific brain inflammation & $\mathrm{TiO}_{2}, \mathrm{MnO}$, Carbon black & $\begin{array}{l}\text { Alzheimer's disease and } \\
\text { Parkinson's disease }\end{array}$ & $130-134$ and $177-179$ \\
\hline \multirow{2}{*}{$\begin{array}{l}\text { Reproductive } \\
\text { system }\end{array}$} & Infertility & Carbon black, $\mathrm{ZnO}$ & Male and female infertility & $140,141,180$ and 181 \\
\hline & Abortion and embryotoxicity & $\begin{array}{l}\mathrm{CNTs} \text {, silica, } \mathrm{TiO}_{2} \text {, carbon } \\
\text { black }\end{array}$ & $\begin{array}{l}\text { Abortion, pre- and post-natal } \\
\text { malformations }\end{array}$ & $138-147$ \\
\hline
\end{tabular}




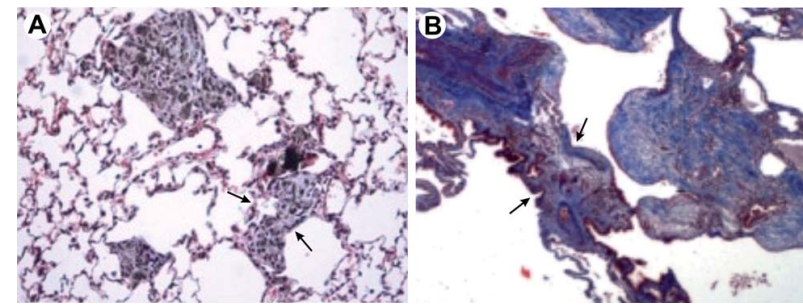

Fig. 2 Lung fibrotic foci induced in mice after exposure to carbon nanotubes (Panel A) and in men with idiopathic pulmonary fibrosis (Panel B). Arrows indicate the fibrotic foci. Different colours are due to the different staining methods. Adapted from X. Wang, P. Katwa, R. Podila, P. Chen, P. C. Ke, A. M. Rao, D. M. Walters, C. J. Wingard, J. M. Brown, Part. Fibre Toxicol., 2011, 8, 24. (Panel A) and adapted with permission from John Wiley and Sons (A. Datta, C. J. Scotton, R. C. Chambers, Br. J. Pharmacol., 2011, 163, 141) (Panel B).

Pleural fibrotic plaques are an important component of asbestosis, a human disease associated with occupational exposure to asbestos. Their occurrence in animals after exposure to CNTs, which share with asbestos the fiber-like shape and biopersistence, is of concern, as well as the reported occurrence in some experiments of mesothelioma, a malignant neoplasia caused by asbestos exposure. For a correct interpretation of the reported relationship between CNT exposure and mesothelioma, it should however be considered that until now there is no experimental demonstration of pleural mesothelioma developing after pulmonary exposure to ENMs: positive association has been reported only through other, nonphysiologic routes of exposure.

\subsection{Human cardio-vascular diseases}

The cardiovascular disorders observed in experimental studies which may be linked to human disorders are: progression of established atherosclerosis, acute thrombosis and arrhythmias. As far as the progression of established atherosclerosis is concerned, of particular interest is the additional role of hyperlipidemic diet and CNT exposure, which implies that ENMs might act in concert with traditional risk factors. The thrombogenic activity in damaged arteries seen in experimental studies

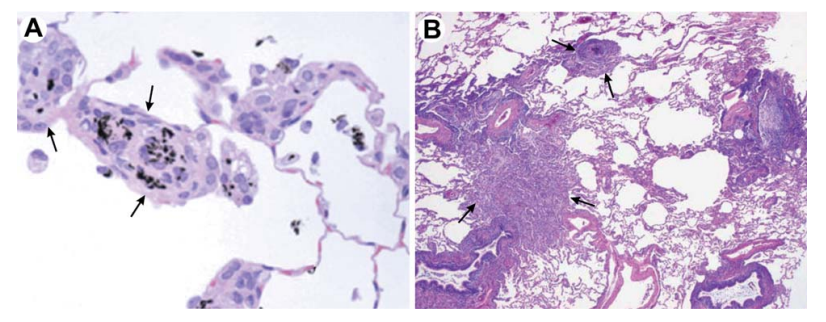

Fig. 3 Pulmonary granulomas in rats exposed to carbon nanotubes (Panel A) and in men with foreign body reaction (Panel B). Arrows indicate granulomatous lesions. Different colours are due to the different staining methods. Black spots inside rat granulomas are due to aggregates of CNTs. Adapted with permission from Oxford University Press from L. Ma-Hock, S. Treumann, V. Strauss, S. Brill, F. Luizi, M. Mertler, K. Wiench, A. O. Gamer, B. van Ravenzwaay, R. Landsiedel, Toxicol. Sci., 2009, 112, 468 (Panel A) and from S. Mulkopadhyay, A. A. Gal, Arch. Pathol. Lab. Med., 2010, 134, 667 (Panel B).

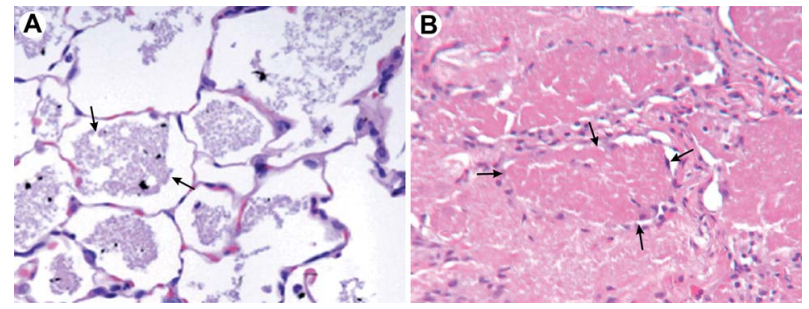

Fig. 4 Presence of proteinaceous material in the lung of rats exposed to carbon nanotubes (Panel A) and of men (Panel B). In both cases a diagnosis of alveolar proteinosis has been made. Arrows indicate the proteinaceous material. Different colours are due to the different staining methods. Adapted with permission from Oxford University Press from L. Ma-Hock, S. Treumann, V. Strauss, S. Brill, F. Luizi, M. Mertler, K. Wiench, A. O. Gamer, B. van Ravenzwaay, R. Landsiedel, Toxicol. Sci., 2009, 112, 468 (Panel A) and from D. Tejwani, A. E. DeLaCruz, M. Niazi, G. Diaz-Fuentes, J. Med. Case Reports, 2011, 5, 46 (Panel B).

evokes the final precipitating event of atherosclerosis: the rupture of the plaque (damaged artery) and the development of an occlusive thrombus causing myocardial infarction or ischemic stroke. Interestingly, epidemiological data link acute exposure to pollution-related NMs to sudden cardiac death, which is in part due to acute ischemic events. ${ }^{110}$

The alteration in the neurologic control of the heart rate (appropriately termed cardiac autonomic control) is of particular concern in subjects with known ischemic heart disease, since it has been shown that these patients are particularly prone to sudden death when this alteration is superimposed to their underlying disorder. ${ }^{175}$

\subsection{Human skin diseases}

Human skin diseases possibly linked to experimental findings are aspecific dermatitis, skin tumours, and foreign body reaction. However, much more data are needed before this possibility can be seriously considered. Although not supported by animal studies, there are two skin conditions reported in humans, which are linked to ENMs exposure: toxic epidermal necrolysis-like dermatitis and argyria. The first has been reported in a chemist exposed to high levels of intermediate or final products of dendrimers while performing dendrimer synthesis. ${ }^{4}$ It is however unclear whether the disease was caused by dendrimers or by reactive species used in their synthesis. The second is a human disorder generally observed after chronic exposure to silver. It would be noted that silver ENMs are present in health products including wound dressings, and that a direct contact with the adnexal structures in the dermis, which are the site of deposition of silver in patients with argyria, is facilitated by this use. Although argyria is a benign condition, it may have cosmetic relevance, since silver deposition and hyperpigmentation of the skin are permanent and there is no effective treatment.

\subsection{Human neurological diseases}

Disruption of the blood-brain barrier and transendothelial migration of activated leukocytes are systemic effects of some ENMs; these events are among the earliest cerebrovascular abnormalities seen in multiple sclerosis (MS), an inflammatory 
demyelinating disease of the central nervous system that develops in genetically susceptible individuals after exposure to currently unknown environmental triggers. ${ }^{176}$ An excess level of inflammation is observed in several neurological diseases such as Alzheimer's disease ${ }^{177}$ and Parkinson's disease. ${ }^{178}$ Although inflammation is not considered the primary trigger of these disorders, it is believed to be causally related, especially in Alzheimer's disease. ${ }^{179}$ Thus, the neuroinflammatory potential of some ENMs may theoretically contribute to the development of severe neurodegenerative diseases.

\subsection{Human reproductive disorders}

Of obvious social and clinical relevance are the possible reprotoxic effects. There is evidence of decreased male fertility in the Western world during the last decades ${ }^{182}$ and exposure in the workplace probably contributes to this outcome. ${ }^{183}$ The effect on female fertility is less certain, and the paucity of data regarding male and female fertility associated with ENM exposure do not currently allow any reliable correlation with clinical events in humans. It should be considered, however, that exposure to pollution-related NMs is associated with male infertility ${ }^{180,181}$ and therefore further research on the role of ENMs is needed. The possible teratogenic effects of some ENMs must be taken into account when planning safety measures in potentially exposed people. A special challenge is represented by the biopersistence of some ENMs which have shown a positive association with developmental toxicity. In theory, even exposure before pregnancy might represent a hazard. Appropriate studies to address this problem are needed.

\subsection{Other human diseases}

Several types of ENMs such as $\mathrm{CeO}_{2}$, QDs, CNTs and $\mathrm{TiO}_{2}$, have been shown to promote protein fibril formation. In particular, $\mathrm{TiO}_{2}$ accelerated the fibrillation of the $\beta$-amyloid peptide, ${ }^{49}$ whereas the other ENMs stimulated faster formation of fibrils of the $\beta$-2-microglobulin amyloid protein. A wide range of human pathologies, including systemic amyloidoses, type II diabetes, and neurodegenerative diseases, are characterized by the anomalous self-assembly and deposition of proteic material into insoluble (ordered) supramolecular structures, such as fibrils, tangles, or aggregates of fibrils.

Finally, there is an almost endless list of human disorders which may in theory be linked to the observed genotoxic and immunotoxic effects. The level of knowledge for these disorders is clearly still inadequate. The clinical consequences, ranging from none to cancer, are of course dependent upon the type of damage elicited by the agent. The ability to predict what kind of damage may be induced by different ENMs under different conditions would be highly desirable, but is currently lacking.

\subsection{Lessons from toxicity of ENMs}

Understanding the mechanisms by which ENMs may cause damage to various organs and organ systems is crucial not only for predicting specific diseases which may develop after human exposure, but may also have two relevant implications: from one side the promotion of research aimed to the production of ENMs safe-by-design, i.e. properly modified in order to maintain the properties pertinent to their industrial usage, and at the same time deprived of those linked to adverse health effects; on the other side, the development of drugs specifically aimed to prevent or counteract the adverse effect of ENMs on the basis of their pathogenetic mechanisms. Not surprisingly, some of these drugs might be ENMs. For example, cerium oxide, an ENM with antioxidant properties, has been recently proposed as a useful therapeutic agent for the disorders induced by other ENMs causing oxidative damage. ${ }^{184}$

\section{Adverse vs. beneficial effects}

Several ENMs produced for the industry have favourable effects on the environment, and, indirectly, on human health. For example, alumina and lanthanum ENMs are used in water filtration and purification, respectively, $\mathrm{TiO}_{2}$ in air filtration processes, and silver ENMs have an extensive use as bactericidals. More important, the biomedical use of ENMs is one of the most relevant applications of nanotechnology. Of course, in the case of biomedical applications, ENM properties are manipulated in a different way than in the case of industrial applications: to aid the transport of diagnostic or therapeutic agents through biologic barriers; to gain access to molecules; to mediate molecular interactions; and to detect molecular changes in a sensitive, high throughput manner.

In terms of health implications, the main difference between ENMs produced for industrial use and those produced for biomedical applications is that until now the negative health effects of the first ones have been observed in cultured cells and animals, but not in humans, whereas the positive health effects of ENMs produced for biomedical purposes are observed in humans.

In Table 5 are listed ENM-based diagnostic devices and therapeutic agents approved for their use by the U.S. Food and Drug Administration (FDA).

An even higher number of ENMs are being evaluated in humans for therapeutic purposes in the context of formal clinical trials. Of note, to be admitted to clinical trials, data

Table 5 Examples of Nanomaterials approved by the Food and Drug Administration for clinical use

\begin{tabular}{llll}
\hline Application & ENM & Specific biomedical use & Manufacturer \\
\hline Imaging & Iron oxide & Contrast agent in magnetic resonance imaging & Bayer Schering/Advanced Magnetics \\
Bioanalysis & Gold & Genetic mutations in patients with suspected thrombophilia & Nanosphere \\
Cancer Therapy & Albumin & Metastatic breast cancer & Abraxix Bioscience \\
Cancer therapy & Liposome & Ovarian cancer, AIDS-related Kaposi's sarcoma, multiple myeloma & Ortho Biotech \\
Cancer therapy & Polymer (PEG) & Acute lymphoblastic leukemia & Rhone-Poulenc Rorer \\
\hline
\end{tabular}


Table 6 ENM based therapeutic agents evaluated in clinical trials

\begin{tabular}{|c|c|c|c|}
\hline Treatment & ENM & Target & $\begin{array}{l}\text { Clinical } \\
\text { trial phase }\end{array}$ \\
\hline Cancer & Iron oxide & $\begin{array}{l}\text { Solid tumors accessible to } \\
\text { direct injection of ENM }\end{array}$ & \\
\hline Cancer & Gold & $\begin{array}{l}\text { Pancreatic cancer, melanoma, } \\
\text { soft tissue sarcoma, ovarian } \\
\text { cancer, breast cancer }\end{array}$ & \\
\hline Cancer & $\begin{array}{l}\text { Gold } \\
\text { nanoshell }\end{array}$ & $\begin{array}{l}\text { Refractory head and } \\
\text { neck cancer }\end{array}$ & \\
\hline Cancer & Polymer & $\begin{array}{l}\text { Recurrent or unresponsive } \\
\text { solid tumours }\end{array}$ & \\
\hline Cancer & Micelle & Various tumours & \\
\hline Infection & Dendrimer & Cervico-vaginal infections & \\
\hline
\end{tabular}

${ }^{a}$ Clinical trials are conducted in a series of steps, called phases - each phase is designed to answer a separate research question. Phase I: researchers test a new drug or treatment in a small group of people for the first time to evaluate its safety, determine a safe dosage range, and identify side effects. Phase II: the drug or treatment is given to a larger group of people to see if it is effective and to further evaluate its safety. Phase III: the drug or treatment is given to large groups of people to confirm its effectiveness, monitor side effects, compare it to commonly used treatments, and collect information that will allow the drug or treatment to be used safely. Phase $I V$ : studies are done after the drug or treatment has been marketed to gather information on the drug's effect in various populations and any side effects associated with longterm use. ${ }^{b}$ This treatment has been recently approved by European Regulatory agencies and is available to patients outside of clinical trials in selected authorized centers in Germany. ${ }^{c}$ In phase 1 for certain infections.

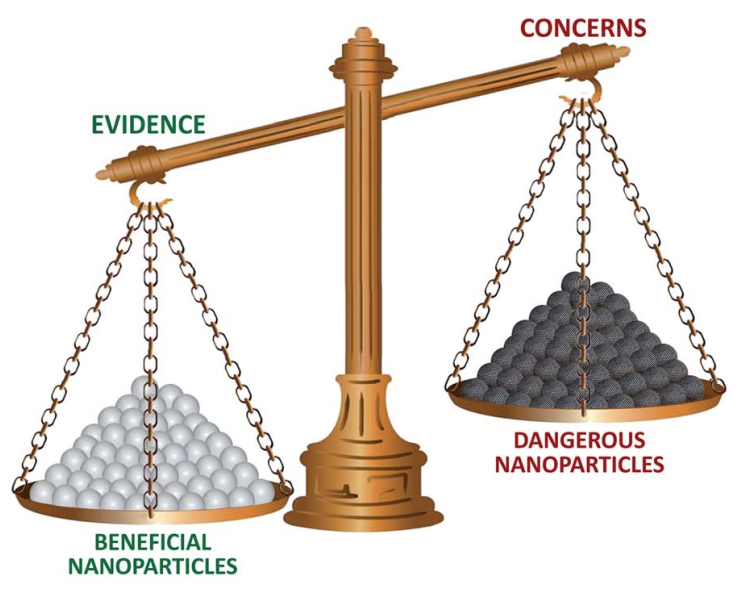

\section{HEALTH BALANCE}

Fig. 5 The weight of evidence. Schematic representation of the current balance between beneficial health effects and adverse health effects of engineered nanomaterials.

demonstrating that the investigational drug is reasonably safe for use in humans must be submitted to governmental agencies.

Table 6 shows ENM based therapeutic agents currently under investigation in clinical trials.

Therefore, although the number of potential human illnesses provoked by exposure to ENMs is almost as high as the number of direct (from biomedical applications) or indirect (from industrial applications) beneficial effect, the weight of the two is quite different (Fig. 5).

\section{Conclusions}

Nanotechnology represents one of the most fascinating developments of science during the last decade. It is peculiarly linked to human health because several products are specifically designed to improve available diagnostic and therapeutic tools or to improve the quality of the environment and therefore the quality of life. Even the branch of nanotechnology oriented to industrial applications has a peculiar impact on human activities in comparison to other technologies, given the almost endless number of fields in which its products may be applied. Nanotechnology must be managed with care, however. The seemingly slight differences between ENMs produced for industrial applications in comparison to those produced for biomedical application may lead to quite divergent outcomes in terms of human health: beneficial from one side, deleterious from the other one. Although we have currently no proof that the expected occupational, consumer or environmental exposure to ENMs may cause any definite disease, the amount of data coming from nanotoxicology during the last decade enables us to identify some potential specific targets: the respiratory system and the cardiovascular system. This is in keeping with the epidemiological data regarding exposure to NMs present in air pollution or to incidental NMs produced by traditional work activities. Therefore, health surveillance should be primarily devoted to prevent disorders of these two systems. In particular, focus should be on pulmonary fibrosis, granulomatous lung disease and asbestosislike disorders for the respiratory tract, and on progression of atherosclerosis for the cardiovascular system. Until specific and reliable ENM biomarkers are available, conventional assessment for the presence and progression of these pleuro-pulmonary and cardiovascular disorders should be implemented, especially in high risk subjects (i.e. those with known disease, and those with other risk factors). The recently reported possible adverse effects on embryo development also suggest special attention to female workers during pregnancy.

The challenge of nanotechnology for the next decade is the production of ENMs for industrial applications which are safeby-design. The development of reliable computational models based on the quantitative nanostructure toxicity relationship (QNTR) approach will probably be of help in reaching this goal.

\section{Acknowledgements}

The author is supported, in part, by a grant from the European Commission (FP7-MARINA, grant agreement no. 263215).

\section{References}

1 Nanoscale Science, Engineering, and Technology (NSET) Workshop Report, Arlington, VA, Lux Research, 2007.

2 K. Donaldson, V. Stone, C. L. Tran, W. Kreyling and P. J. Borm, Occup. Environ. Med., 2004, 61, 727.

3 Y. Song, X. Li and X. Du, Eur. Respir. J., 2009, 34, 559.

4 T. Toyama, H. Matsuda, I. Ishida, M. Tani, S. Kitaba, S. Sano and I. Katayama, Contact Dermatitis, 2009, 59, 122.

5 J. I. Phillips, F. Y. Green, J. C. Davies and J. Murray, Am. J. Ind. Med., 2010, 53, 763

6 G. Oberdorster, J. Intern. Med., 2010, 267, 89

7 D. M. Brown, M. R. Wilson, W. MacNee, V. Stone and K. Donaldson, Toxicol. Appl. Pharmacol., 2001, 175, 191. 
8 Q. Zhang, Y. Kusaka, X. Zhu, K. Sato, Y. Mo, T. Kluz and K. Donaldson, J. Occup. Health, 2003, 45, 23.

9 G. Oberdorster, E. Oberdorster and J. Oberdorster, Environ. Health Perspect., 2005, 113, 823 .

10 D. Dankovic, E. Kuempel and M. Wheeler, Inhalation Toxicol., 2007, 19, 205.

11 T. M. Sager, C. Kommineni and V. Castranova, Part. Fibre Toxicol., 2008, 5, 17

12 W. S. Cho, R. Duffin, C. A. Poland, S. E. Howie, W. MacNee, M. Bradley, I. L. Megson and K. Donaldson, Environ. Health Perspect., 2010, 118, 1699

13 P. J. Borm, D. Robbins, S. Haubold, T. Kuhlbusch, H. Fissan, K. Donaldson, R. Schins, V. Stone, W. Kreyling, J. Lademann, J. Krutmann, D. Warheit and E. Oberdorster, Part. Fibre Toxicol., 2006, 14, 3 .

14 M. Auffan, J. Rose, J. Y. Bottero, G. V. Lowry, J. P. Jolivet and M. R. Wiesner, Nat. Nanotechnol., 2009, 4, 634.

15 D. B. Warheit, B. R. Laurence, K. L. Reed, D. H. Roach, G. A. Reynolds and T. R. Webb, Toxicol. Sci., 2004, 77, 117.

16 P. Wick, P. Manser, L. K. Limbach, U. Dettlaff-Weglikowska, F. Krumeich, S. Roth, W. J. Stark and A. Bruinink, Toxicol. Lett, 2007, 168, 121.

17 I. Gosens, J. A. Post, L. J. J. De la Fonteyne, E. H. J. M. Jansen, J. W. Geus, F. R. Cassee and W. H. De Jong, Part. Fibre Toxicol., 2011, 7, 37.

18 K. Donaldson, F. A. Murphy, R. Duffin and C. A. Poland, Part. Fibre Toxicol., 2010, 22, 5.

19 C. A. Poland, R. Duffin, I. Kinlock, A. Maynard, W. A. H. Wallace, A. Seaton, V. Stone, S. Brown, W. MacNee and K. Donaldson, Nat. Nanotechnol., 2008, 3, 423.

20 F. Murphy, R. Duffin, C. A. Poland, K. T. Al-Jamal, H. AliBoucetta, N. Nunes, F. Byrne, A. Prina-Mello, Y. Volkov, S. Li, S. J. Mather, A. Bianco, M. Prato, W. MacNee, W. A. Wallace, K. Kostarelos and K. Donaldson, Am. J. Pathol., 2011, 178, 2587.

21 A. E. Nel, L. Mädler, D. Velegol, T. Xia, E. M. V. Hoek, P. Somasundaran, F. Klaessig, V. Castranova and M. Thompson, Nat. Mater., 2009, 8, 543.

22 N. M. Schaeublin, L. K. Braydich-Stolle, A. M. Schrand, J. M. Miller, J. Hutchison, J. J. Schlager and S. M. Hussain, Nanoscale, 2011, 3, 410.

23 T. C. K. Heiden, E. Dengler, W. J. Kao, W. Heideman and R. E. Peterson, Toxicol. Appl. Pharmacol., 2007, 225, 70.

24 S. Bhattacharjee, L. H. J. de Haan, N. M. Evers, X. Jiang, A. T. M. Marcelis, H. Zuilhof, I. M. C. M. Rietjens and G. M. Alink, Part. Fibre Toxicol., 2010, 7, 25.

25 A. Hoshino, K. Fujioka, T. Oku, M. Suga, Y. F. Sasaki, T. Ohta, M. Yasuhara, K. Suzuki and K. Yamamoto, Nano Lett., 2004, 4 2163.

26 J. M. Pettibone, A. Adamcakova-Dodd, P. S. Thorne, P. T. O'Shaughnessy, J. A. Weydert and V. H. Grassian, Nanotoxicology, 2008, 2, 189.

27 J. Jiang, G. Oberdorster, A. Elder, R. Gelein, P. Mercer and P. Biswas, Nanotoxicology, 2008, 2, 33.

28 C. M. Sayes, R. Wahi, P. A. Kurian, Y. P. Liu, J. L. West, K. D. Ausman, D. B. Warheit and V. L. Colvin, Toxicol. Sci., 2006, 92, 174.

29 K. Donaldson, P. J. Borm, V. Castranova and M. Gulumian, Part. Fibre Toxicol., 2009, 6, 13.

30 B. Halliwell and J. M. C. Gutteridge, in Reactive Species can be Poisonous, in Free Radicals in Biology and Medicine, ed. B. Halliwell and J. M. C. Gutteridge, Oxford University Press, New York, 4th edn, 2007, pp. 440-487.

31 A. Nel, T. Xia, L. Madler and N. Li, Science, 2006, 311, 622.

32 M. Ahamed, M. A. Siddiqui, M. J. Akhtar, I. Ahmad, A. B. Pant and H. A. Alhadlaq, Biochem. Biophys. Res. Commun., 2010, 396, 578.

33 R. Schins and K. Donaldson, Inhalation Toxicol., 2000, 12(suppl. 3), 317

34 A. Shvedova, E. R. Kisin, R. Mercer, A. R. Murray, V. J. Johnson, A. I. Potapovich, Y. Y. Tyurina, O. Gorelik, D. Schwegler-Berry, A. F. Hubbs, J. Antonini, D. E. Evans, B. K. Ku, D. Ramsey, A. Maynard, V. Kagan, V. Castranova and P. Baron, Am. J. Physiol.: Lung Cell. Mol. Phys., 2005, 289, 698.

35 A. Shvedova, E. R. Kisin, A. R. Murray, V. J. Johnson, O. Gorelik, S. Arepalli, A. F. Hubbs, R. Mercer, P. Keohavong, N. Sussman,
J. Jin, S. Stone, B. T. Chen, G. Deye, A. Maynard, V. Castranova, P. A. Baron and V. E. Kagan, Am. J. Physiol.: Lung Cell. Mol. Phys., 2008, 295, L552.

36 I. Lynch and K. A. Dawson, Nano Today, 2008, 3, 40.

37 M. P. Monopoli, D. Walczyk, A. Campbell, G. Elia, I. Lynch, F. B. Bombelli and K. A. Dawson, J. Am. Chem. Soc., 2011, 133, 2525.

38 E. Casals, T. Pfaller, A. Duschl, G. J. Oostingh and V. Puntes, ACS Nano, 2010, 4, 3623.

39 H. Zhang, K. E. Burnum, M. L. Luna, B. O. Petritis, J.-S. Kim W.-J. Qian, R. J. Moore, A. Heredia-Langner, B.-J. M. WebbRobertson, B. D. Thrall, D. G. Camp, R. D. Smith, J. G. Pounds and T. Liu, Proteomics, 2011, 11, 4569.

40 E. Casals, T. Pfaller, A. Duschl, G. J. Oostingh and V. F. Puntes, Small, 2011, 7, 3479.

41 M. Lundqvist, J. Stigler, G. Elia, I. Lynch, T. Cedervall and K. A. Dawson, Proc. Natl. Acad. Sci. U. S. A., 2008, 105, 14265.

42 D. Dell'Orco, M. Lundqvist, C. Oslakovic, T. Cedervall and S. Linse, PLoS One, 2010, 5, e10949.

43 M. Lundqvist, J. Stigler, T. Cedervall, T. Berggard, M. B. Flanagan, I. Lynch, G. Elia and K. Dawson, ACS Nano, 2011, 5, 7503.

44 M. Demoy, S. Gibaud, J. P. Andreux, C. Weingarten, B. Gouritin and P. Couvreur, Pharm. Res., 1997, 14, 463.

45 E. Sadauskas, H. Wallin, M. Stoltenberg, U. Vogel, P. Doering, A. Larsen and G. Danscher, Part. Fibre Toxicol., 2007, 4, 10.

46 R. M. Koffie, C. T. Farrar, L.-J. Saidi, C. M. William, B. T. Hyman and T. L. Spires Jones, Proc. Natl. Acad. Sci. U. S. A., 2011, 108, 18837.

47 R. Singh, D. Pantarotto, L. Lacerda, G. Pastorin, C. Klumpp, M. Prato, A. Bianco and K. Kostarelos, Proc. Natl. Acad. Sci. U. S. A., 2006, 103, 3357.

48 Z. J. Deng, M. Liang, M. Monteiro, I. Toth and R. F. Minchin, Nat. Nanotechnol., 2011, 6, 39-44.

49 S. Linse, C. Cabaleiro-Lago, W.-F. Xue, I. Lynch, S. Lindman, E. Thulin, S. E. Radford and K. A. Dawson, Proc. Natl. Acad. Sci. U. S. A., 2007, 104, 8691

50 W.-H. Wu, X. Sun, Y.-P. Yu, J. Hu, L. Zhao, Q. Liu, Y.-F. Zhao and Y.-M. Li, Biochem. Biophys. Res. Commun., 2008, 373, 315.

51 R. M. Koffie, C. T. Farrar, L.-J. Saidi, C. M. William, B. T. Hyman and T. L. Spires Jones, Proc. Natl. Acad. Sci. U. S. A., 2011, DOI: $10.1073 /$ pnas. 1111405108 .

52 Y. Song, X. Li, L. Wang, Y. Rojanasakul, V. Castranova, H. Li and J. Ma, Toxicol. Pathol., 2011, 39, 841 .

53 Commission Recommendations of 18 October 2011 on the definition of nanomaterial (text with EEA relevance). Off. $J$. Eur. Communities: Legis., 20/10/2011, 275, 38.

54 Organization for Economic Cooperation and Development (OECD) [homepage on the internet], Paris: Safety of Manufactured Nanomaterials, accessed 18 August 2011, http://www.oecd.org/ about/0, 3347, en_2649_37015404_1_1_1_1_37465,00.html.

55 Organization for Economic Cooperation and Development (OECD) [publication on the internet], Paris: OECD 2010, Guidance manual for the testing of manufactured nanomaterials: OECD's Sponsorship programme; first revision, ENV/JM/MONO(2009)20/ REV (2010 June 02). accessed 18 August 2011, http:// www.oecd.org/officialdocuments/displaydocumentpdf/?cote=env/ $\mathrm{jm} / \mathrm{mono}(2009) 20 / \mathrm{rev} \&$ doclanguage $=\mathrm{en}$

56 European Communities, Luxembourg 2000: Commission Directive 2000/39/EC of 8 June 2000 establishing a first list of indicative occupational exposure limit in implementation of Council Directive 98/24/EC on the protection of the health and safety of workers from the risks related to chemical agents at work. Publications Office of the European Union, Off. J. Eur. Communities: Legis., 16.6.2000, 142, 47-50.

57 European Union, Luxembourg 2006: Commission Directive 2006/ 15/EC of 7 February 2006 establishing a second list of indicative occupational exposure limit in implementation of Council Directive 98/24/EC and amending Directives 91/322/EEC and Directive 2000/39/EC. Publications Office of the European Union, Off. J. Eur. Communities: Legis., 9.2.2006, 38, 36-39.

58 NIOSH, Occupational exposure to Titanium dioxide. current intelligent bulletin 63, accessed 23 August 2011, http:// www.cdc.gov/niosh/docs/2011-160/pdfs/2011-160.pdf, 2011.

59 M. Methner, L. Hodson and C. Geraci, J. Occup. Environ. Hyg., $2010,7,127$ 
60 M. Methner, L. Hodson, A. Dames and C. Geraci, J. Occup. Environ. Hyg., 2010, 7, 163.

61 U.S. National Institute for Occupational Safety and Health, Centers for Disease Control and Prevention, 2009, Publication No. 2009125.

62 S. J. Tsai, R. F. Huang and M. J. Ellenbecker, Ann. Occup. Hyg., 2010, 54, 78.

63 P. Gao, P. A. Jacques, T.-C. Hsiao, A. Shepherd, B. C. Eimer, M. Yang, A. Miller, B. Gupta and R. Shaffer, J. Occup. Environ Hyg., 2011, 8, 13 .

64 S. Rengasamy, B. C. Eimer and R. E. Shaffer, Ann. Occup. Hyg., 2009, 53, 117.

65 S. W. P. Wijnhoven, S. Dekkers, W. I. Hagens, W. H. de Jong, RVIM Report 3403700001, 2009.

66 J. Wang, G. Zhoua, C. Chena, H. Yu, T. Wang, Y. Mad, G. Jia, Y. Gaoa, B. Li, J. Suna, Y. Li, F. Jiao, Y. Zhaoa and Z. Chai, Toxicol. Lett., 2007, 168, 176.

67 Y. S. Kim, J. S. Kim, H. S. Cho, D. S. Rha, J. M. Kim, J. D. Park, B. S. Choi, R. Lim, H. K. Chang, Y. H. Chung, I. H. Kwon, J. Jeong, B. S. Han and I. J. Yu, Inhalation Toxicol., 2008, 20, 575.

68 E. J. Park, J. Yi, Y. Kim, K. Choi and K. Park, Toxicol. in Vitro, 2010, 24, 872

69 C. Schleh, M. Semmler-Behnke, J. Lipka, A. Wenk, S. Hirn, M. Scheffler, G. N. Schmid, U. Simon and W. G. Kreyling, Nanotoxicology, 2011, DOI: 10.3109/17435390.2011.552811.

70 C.-H. Li, C.-C. Shen, Y.-W. Cheng, S.-H. Wang, C.-C. Wu, C.-C. Kao, J.-W. Liao and J.-J. Kang, Nanotoxicology, 2011, DOI: 10.3109/17435390.2011.620717.

71 N. A. Monteiro-Riviere and J. E. Riviere, Nanotoxicology, 2009, 3, 188 .

72 S. Breitner, M. Stolzel, J. Cyrys, M. Pitz, G. Wolke, W. Kreyling, H. Kuchenoff, J. Heinrich, H.-E. Wichmann and A. Peters, Environ. Health Perspect., 2009, 117, 448.

73 G. S. Kang, P. A. Gillespie, A. Gunnison, A. L. Moreira, K.-M. Tchou-Wong and L.-C. Chen, Environ. Health Perspect., 2011, 119, 176.

74 T. L. Knuckles, J. Yi, D. G. Frazer, H. D. Leonard, B. T. Chen, V. Castranova and T. R. Nurkiewicz, Nanotoxicology, 2011, DOI: 10.3109/17435390.2011.606926.

75 S. von Klot, G. Wolke, T. Tuch, J. Heinrich, D. W. Dockery, J. Schwartz, W. Kreyling, H.-E. Wichmann and A. Peters, Eur Respir. J., 2002, 20, 691.

76 J. McCreanor, P. Cullinan, M. J. Nieuwenhuijsen, J. Stewart-Evans, E. Malliarou, L. Jarup, R. Harrington, M. Svartengren, I. K. Han, P. Ohman-Strickland, K. F. Chung and J. Zhang, N. Engl. J. Med., 2007, 357, 2348.

77 E. A. Eisen, S. Costello, J. Chevrier and S. Picciotto, J. Occup. Environ. Med., 2011, 53(suppl), S57.

78 M. Geiser and W. G. Kreyling, Part. Fibre Toxicol., 2010, 7, 2.

79 G. S. Kang, P. A. Gillespie, A. Gunnison, H. Rengifo, J. Koberstein and L. C. Chen, Inhalation Toxicol., 2011, 23, 95.

80 L. Ma-Hock, S. Burkhardt, V. Strauss, A. O. Gamer, K. Wiench, B. van Ravenzwaay and R. Landsiedel, Inhalation Toxicol., 2009, 21, 102.

81 Y. Morimoto, A. Ogami, M. Todoroki, M. Yamamoto, M. Murakami, M. Hirohashi, T. Oyabu, T. Myojo, K. Nishi, C. Kadoya, S. Yamasaki, H. Nagatomo, K. Fujita, S. Endoh, K. Uchida, K. Yamamoto, N. Kobayashi, J. Nakanishi and I. Tanaka, Nanotoxicology, 2010, 4, 161.

82 P. A. Gillespie, G. S. Kang, A. Elder, R. Gelein, L. Chen, A. L. Moreira, J. Koberstein, K. M. Tchou-Wong, T. Gordon and L. C. Chen, Nanotoxicology, 2010, 4, 119

83 A. Ogami, Y. Morimoto, T. Myojo, T. Oyabu, M. Murakami, M. Todoroki, K. Nishi, C. Kadoya, M. Yamamoto and I. Tanaka, Inhalation Toxicol., 2009, 2, 1818.

84 W. S. Cho, R. Duffin, S. E. Howie, C. J. Scotton, W. A. H. Wallace, W. MacNee, M. Bradley, I. L. Megson and K. Donaldson, Part. Fibre Toxicol., 2011, 8, 27.

85 L. Wang, R. R. Mercer, Y. Rojanasakul, A. Qiu, Y. Lu, J. F. Scabilloni, N. Wu and V. Castranova, J. Toxicol. Environ. Health, Part A, 2010, 73, 410 .

86 X. Wang, P. Katwa, R. Podila, P. Chen, P. C. Ke, A. M. Rao, D. M. Walters, C. J. Wingard and J. M. Brown, Part. Fibre Toxicol., 2011, 8, 24.
87 C. W. Lam, J. T. James, R. McCluskey and R. L. Hunter, Toxicol. Sci., 2004, 77, 126

88 J. Muller, F. Huaux, N. Moreau, P. Misson, J. F. Heilier, M. Delos, M. Arras, A. Fonseca, J. B. Nagy and D. Lison, Toxicol. Appl. Pharmacol., 2005, 207, 221.

89 D. B. Warheit, Carbon, 2006, 44, 1069.

90 Z. Li, T. Hulderman, T. Salmen, R. Chapman, S. S. Leonard, S. Young, A. Shvedova, M. I. Luster and P. P. Simeonova, Environ. Health Perspect., 2007, 115, 377.

91 C. C. Chou, H. Y. Hsiao, Q. S. Hong, C. H. Chen, Y. W. Peng, H. W. Chen and P. C. Yang, Nano Lett., 2008, 8, 445.

92 A. Al Faraj, A. Bessaad, K. Cieslar, G. Lacroix, E. Canet-Soulas and Y. Cremillieux, Nanotechnology, 2010, 21, 17.

93 R. F. Hamilton, N. Wu, D. Porter, M. Buford, M. Wolfarth and A. Holian, Part. Fibre Toxicol., 2009, 6, 35.

94 R. R. Mercer, J. Scabilloni, L. Wang, E. Kisin, A. R. Murray, D. Schwegler-Berry, A. A. Shvedova and V. Castranova, Am. J. Physiol.: Lung Cell. Mol. Phys., 2008, 294, L87.

95 H. Ellinger-Ziegelbauer and J. Pauluhn, Toxicology, 2009, 266, 16

96 L. Ma-Hock, S. Treumann, V. Strauss, S. Brill, F. Luizi, M. Mertler, K. Wiench, A. O. Gamer, B. van Ravenzwaay and R. Landsiedel, Toxicol. Sci., 2009, 112, 468.

97 J. P. Ryman-Rasmussen, M. F. Cesta, A. R. Brody, J. K. ShipleyPhillips, J. I. Everitt, E. W. Tewksbury, O. R. Moss, B. A. Wong, D. E. Dodd, M. E. Andersen and J. C. Bonner, Nat. Nanotechnol., 2009, 4, 747.

98 C. Boutin, P. Dumortier, F. Rey, J. R. Viallat and P. De Vuyst, Am. J. Respir. Crit. Care Med., 1996, 153, 444.

99 C. A. Poland, F. Byrne, W.-S. Cho, A. Prina-Mello, F. A. Murphy, G. L. Davies, J. M. D. Coey, Y. Gounko, R. Duffin, Y. Volkov and K. Donaldson, Nanotoxicology, 2011, DOI: 10.3109/ 17435390.2011 .626535

100 A. Takagi, A. Hirose, T. Nishimura, N. Fukumori, A. Ogata, N. Ohashi, S. Kitajima and J. Kanno, J. Toxicol. Sci., 2008, 33, 105

101 J. Muller, M. Delos, N. Panin, V. Rabolli, F. Huaux and D. Lison, Toxicol. Sci., 2009, 110, 442.

102 A. O. Inman, C. M. Sayes, V. L. Colvin and N. A. Monteiro-Riviere, Toxicol. Sci., 2006, 90(Suppl. 1), 167.

103 A. A. Shvedova, V. Castranova, E. Kisin, D. Schwegler-Berry, A. Murray, V. Gandlelsman, A. Maynard and P. Baron, $J$. Toxicol. Environ. Health, Part A, 2003, 66, 1909.

104 N. A. Monteiro-Riviere, R. J. Nemanich, A. O. Inman, Y. Y. Wang and J. E. Riviere, Toxicol. Lett., 2005, 155, 377.

105 J. P. Ryman-Rasmussen, J. E. Riviere and N. A. Monteiro-Riviere, J. Invest. Dermatol., 2007, 127, 143.

106 C. Sayes, R. Wahi, P. Kurian, Y. Liu, J. West, K. Ausman, D. Warheit and V. Colvin, Toxicol. Sci., 2006, 92, 174.

107 A. Murray, E. Kisin, S. S. Leonard, S. H. Young, C. Kommineni, V. E. Kagan, V. Castranova and A. A. Shvedova, Toxicology, $2009,257,161$

108 M. A. Nelson, E. D. Frederick, G. T. Bowden, S. B. Hooser, Q. Fernando and D. E. Carter, Toxicol. Ind. Health, 1993, 9, 623.

109 A. Yokoyama, Y. Sato, Y. Nodasaka, S. Yamamoto, T. Kawasaki, M. Shindoh, T. Kohgo, T. Akasaka, M. Uo, F. Watari and T. Kazuyuki, Nano Lett., 2005, 5, 157.

110 K. Donaldson, L. Tran, L. Jimenez, R. Duffin, D. E. Newby, N. Mills, W. MacNee and V. Stone, Part. Fibre Toxicol., 2005, 2, 10.

111 R. D. Brook, S. Rajagopalan, C. A. Pope, 3rd, J. R. Brook, A. Bhatnagar, A. V. Diez-Roux, F. Holguin, Y. Hong, R. V. Luepker, M. A. Mittleman, A. Peters, D. Siscovick, S. C. Smith, Jr, L. Whitsel and J. D. Kaufman, Circulation, 2010, 121, 2331

112 P. Moller, L. Mikkelsen, L. K. Vesterdal, J. K. Folkmann, L. Forchhammer, M. Roursgaard, P. H. Danielsen and S. Loft, Crit. Rev. Toxicol., 2011, 41, 339.

113 A. Radomski, P. Jurasz, D. Alonso-Escolano, M. Drews, M. Morandi, T. Malinski and M. W. Radomski, Br. J. Pharmacol., 2005, 146, 882.

114 C. McGuinnes, R. Duffin, S. Brown, N. Mills, I. L. Megson, W. MacNee, S. Johnston, S. L. Lu, L. Tran, R. Li, X. Wang, D. E. Newby and K. Donaldson, Toxicol. Sci., 2011, 119, 359.

115 A. Erdely, T. Hulderman, R. Salmen, A. Liston, P. C. ZeidlerErdely, D. Schwegler-Berry, V. Castranova, S. Koyama, Y.-A. Kim, M. Endo and P. P. Simeonova, Nano Lett., 2009, 9, 36. 
116 M. T. Zhu, B. Wang, Y. Wang, L. Yuan, H. J. Wang, M. Wang, H. Ouyang, Z. F. Chai, W. Y. Feng and Y. L. Zhao, Toxicol. Lett., 2011, 203, 162.

117 R. Ross, N. Engl. J. Med., 1999, 340, 115.

118 N. J. Wald and M. R. Law, Br. Med. J., 2003, 326, 1419.

119 P. Moller, L. Mikkelsen, L. K. Vesterdal, J. K. Folkmann, L. Forchhammer, M. Roursgaard, P. H. Danielsen and S. Loft, Crit. Rev. Toxicol., 2011, 41, 339.

120 G. S. Kang, P. A. Gillespie, A. Gunnison, A. L. Moreira, K.-M. Tchou-Wong and L.-C. Chen, Environ. Health Perspect., 2011, 119, 176.

121 A. Nemmar, P. H. M. Hoet, P. Vandervoort, D. Dinsdale, B. Nemery and M. F. Hoylaers, J. Thromb. Haemostasis, 2007, 1217.

122 J. M. Legramante, F. Valentini, A. Magrini, G. Palleschi, S. Sacco, I. Iavicoli, M. Pallante, D. Moscone, A. Galante, E. Bergamaschi, A. Bergamaschi and A. Pietroiusti, Hum. Exp. Toxicol., 2009, 28, 369.

123 A. Stampfl, M. Maier, R. Radykewicz, P. Reitmeir, M. Gottlicher and R. Niessner, ACS Nano, 2011, 5, 5345.

124 T. R. Nurkiewicz, D. W. Porter, A. F. Hubbs, S. Stone, B. T. Chen, D. Frazer, M. A. Boegehold and V. Castranova, Toxicol. Sci., 2009, 110, 191.

125 A. J. LeBlanc, A. M. Moseley, B. T. Chen, D. Frazer, V. Castranova and T. R. Nurkiewicz, Cardiovasc. Toxicol., 2010, 10, 27.

126 M. Simkò and M.-O. Mattsson, Part. Fibre Toxicol., 2010, 7, 42.

127 H. S. Sharma, Nanomedicine, 2007, 2, 753.

128 L. Chen, R. A. Yokel, B. Hennig and M. Toborek, J. Neuroimmune Pharmacol., 2008, 3, 286.

129 W. J. Trickler, S. M. Lantz, R. C. Murdock, A. M. Schrand, B. L. Robinson, G. D. Newport, J. J. Schlager, S. J. Oldenburg, M. G. Paule, W. Slikker, Jr, S. M. Hussain and S. F. Ali, Toxicol. Sci., 2010, 118, 160 .

130 A. Elder, R. Gelein, V. Silva, T. Feikert, L. Opanashuk, J. Carter, R. Potter, A. Maynard, Y. Ito, J. Finkelstein and G. Oberdörster, Environ. Health Perspect., 2006, 114, 1172.

131 T. T. Win-Shwe, D. Mitsushima, S. Yamamoto, A. Fukushima, T. Funabashi, T. Kobayashi and H. Fujimaki, Toxicol. Appl. Pharmacol., 2008, 226, 192.

132 J. A. Shin, E. J. Lee, S. M. Seo, H. S. Kim, J. L. Kang and E. M. Park, Neuroscience, 2010, 165, 445.

133 A. Campbell, M. Oldham, A. Becaria, S. C. Bondy, D. Meacher, C. Sioutas, C. Misra, L. B. Mendez and M. Kleinman, NeuroToxicology, 2005, 26, 133.

134 M. T. Kleinman, J. A. Araujo, A. Nel, C. Sioutas, A. Campbell, P. Q. Cong, H. Li and S. C. Bondy, Toxicol. Lett., 2008, 178, 127.

135 K. Takeda, K. Suzuki, A. Ishihara, M. Kubo-Irie, R. Fujimoto, M. Tabata, S. Oshio, Y. Nihei, T. Ihara and M. Sugamata, J. Health Sci., 2009, 55, 95.

136 T. Tsuchiya, I. Oguri, Y. N. Yamakoshi and N. Miyata, FEBS Lett., 1996, 393, 139.

137 P. Wick, A. Malek, P. Manser, D. Meili, X. Maeder-Althaus, L. Diener, P. A. Diener, A. Zisch, H. F. Krug and U. von Mandach, Environ. Health Perspect., 2010, 118, 432.

138 K. Yamashita, Y. Yoshioka, K. Higashisaka, K. Mimura, Y. Morishita, M. Nozaki, T. Yoshida, T. Ogura, H. Nabeshi, K. Nagano, Y. Abe, H. Kamada, Y. Monobe, T. Imazawa, H. Aoshima, K. Shishido, Y. Kawai, T. Mayumi, S. Tsunoda, N. Itoh, T. Yoshikawa, I. Yanagihara, S. Saito and Y. Tsutsumi, Nat. Nanotechnol., 2011, 6, 321.

139 A. Pietroiusti, M. Massimiani, I. Fenoglio, M. Colonna, F. Valentini, G. Palleschi, A. Camaioni, A. Magrini, G. Siracusa, A. Bergamaschi, A. Sgambato and L. Campagnolo, ACS Nano, $2011,5,4624$.

140 S. Yoshida, K. Hiyoshi, T. Ichinose, H. Takano, S. Oshio, I. Sugawara, K. Takeda and T. Shibamoto, Int. J. Androl., 2009, 32, 337.

141 H. Zhang, D. Yang, H. Yang and H. Liu, Weisheng Yanjiu, 2008, 37, $654-656$.

142 T. Tsuchiya, I. Oguri, Y. N. Yamakoshi and N. Miyata, FEBS Lett., 1996, 393, 139.

143 X. Gao, S. Yin, M. Tang, J. Chen, Z. Yang, W. Zhang, L. Chen, B. Yang, Z. Li, Y. Zha, D. Ruan and M. Wang, Biol. Trace Elem. Res., 2011, 143, 1616.

144 M. Shimizu, H. Tainaka, T. Oba, K. Mizuo, M. Umezawa and K. Takeda, Part. Fibre Toxicol., 2009, 6, 20.
145 K. S. Hougaard, P. Jackson, K. A. Jensen, J. J. Sloth, K. Loschner, E. H. Larsen, R. K. Birkedal, A. Vibenholt, A. M. Boisen, H. Wallin and U. Vogel, Part. Fibre Toxicol., 2010, 7, 16.

146 X. Gao, S. Yin, M. Tang, J. Chen, Z. Yang, W. Zhang, L. Chen, B. Yang, Z. Li, Y. Zha, D. Ruan and M. Wang, Biol. Trace Elem. Res., 2011, DOI: 10.1007/s12011-011-8990-4.

147 P. Jackson, K. S. Hougaard, A. M. Boisen, N. R. Jacobsen, K. A. Jensen, P. Møller, G. Brunborg, K. B. Gutzkow, O. Andersen, S. Loft, U. Vogel and H. Wallin, Nanotoxicology, 2011, DOI: $10.3109 / 17435390.2011 .587902$.

148 M. Chen and A. von Mikecz, Exp. Cell Res., 2005, 305, 5162 .

149 I. Nabiev, S. Mitchell, A. Davies, Y. Williams, D. Kelleher, R. Moore, Y. K. Gun'ko, S. Byrne, Y. P. Rakovich, J. F. Donegan, A. Sukhanova, J. Conroy, D. Cottell, N. Gaponik, A. Rogach and Y. Volkov, Nano Lett., 2007, 7, 3452.

150 S. Hackenberg, G. Friehs, K. Froelich, C. Ginzkey, C. Koehler, A. Scherzed, M. Burghartz, R. Hagen and N. Kleinsasser, Toxicol. Lett., 2010, 195, 9.

151 S. Hackenberg, A. Scherzed, A. Technau, M. Kessler, K. Froelich, C. Ginzkey, C. Koehler, M. Burghartz, R. Hagen and N. Kleinsasser, Toxicol. in Vitro, 2011, 25, 657.

152 R. K. Shukla, V. Sharma, A. K. Pandey, S. Singh, S. Sultana and A. Dhawan, Toxicol. in Vitro, 2011, 25, 231.

153 M. S. Cooke, M. D. Evans, M. Dizdaroglu and J. Lunec, FASEB J., 2003, 17, 1195

154 M. Chen and A. von Mikecz, Exp. Cell Res., 2005, 305, 51.

155 L. M. Sargent, A. A. Shvedova, A. F. Hubbs, J. L. Salisbury, S. A. Benkovic, M. L. Kashon, D. T. Lowry, A. R. Murray, E. R. Kisin and S. Friend, Environ. Mol. Mutagen., 2009, 50, 708.

156 J. K. Folkmann, L. Risom, N. R. Jacobsen, H. Wallin, S. Loft and P. Moller, Environ. Health Perspect., 2009, 117, 703.

157 B. Trouiller, R. Reliene, A. Westbrook, P. Solaimani and R. H. Schiestl, Cancer Res., 2009, 69, 8784.

158 A. Balasubramanyam, N. Sailaja, M. Mahboob, M. F. Rahman, S. M. Hussain and P. Grover, Mutagenesis, 2009, 24, 245.

159 L. A. Mitchell, F. T. Lauer, S. W. Burchiel and J. D. McDonald, Nat. Nanotechnol., 2009, 4, 451.

160 B. C. Braden, F. A. Goldbaum, B. X. Chen, A. N. Kirschner, S. R. Wilson and B. F. Erlanger, Proc. Natl. Acad. Sci. U. S. A., 2000, 97, 12193

161 S. C. Lee, R. Parthasarathy, K. Botwin, D. Kunneman, E. Rowold, G. Lange, J. Klover, A. Abegg, J. Zobel, T. Beck, T. Miller, W. Hood, J. Monahan, J. P. McKearn, R. Jansson and C. F. Voliva, Biomed. Microdevices, 2004, 6, 191.

162 U. C. Nygaard, J. S. Hansen, M. Samuelsen, T. Alberg, C. D. Marioara and M. Lovik, Toxicol. Sci., 2009, 109, 113.

163 T. Yoshida, Y. Yoshioka, M. Fujmura, K. Yamashita, K. Higashisaka, H. Kayamuro, H. Nabeshi, K. Nagano, Y. Abe, H. Kamada, S. Tsunoda, N. Itoh, T. Yoshikawa and Y. Tsutsumi, Nanoscale Res. Lett., 2011, 6, 195.

164 M. L. Schipper, N. Nakayama-Ratchford, C. R. Davis, N. W. Kam, P. Chu, Z. Liu, X. Sun, H. Dai and S. S. Gambhir, Nat. Nanotechnol., 2008, 3, 216.

165 T. S. Hauck, R. E. Anderson, S. Newbigging and W. C. W. Chan, Small, 2010, 6, 138.

166 A. A. Shvedova, J. P. Fabisiak, E. R. Kisin, A. R. Murray, J. R. Roberts, Y. Y. Tyurina, J. M. Antonini, W. H. Feng, C. Kommineni, J. Reynolds, A. Barchowsky, V. Castranova and V. E. Kagan, Am. J. Respir. Cell Mol. Biol., 2008, 38, 579.

167 M. A. Matthay and R. L. Zemans, Annu. Rev. Pathol.: Mech. Dis., $2011,6,163$.

168 B. M. Stramer, R. Mori and P. Martin, J. Invest. Dermatol., 2007, 127, 1009 .

169 A. Datta, C. J. Scotton and R. C. Chambers, Br. J. Pharmacol., $2011, \mathbf{1 6 3}, 141$

170 L. Richeldi, Acta Biomed., 2005, 76(suppl. 2), 11.

171 S. Mulkopadhyay and A. A. Gal, Arch. Pathol. Lab. Med., 2010, 134, 667.

172 M. A. McCawley, M. S. Kent and M. T. Berakis, Appl. Occup. Environ. Hyg., 2001, 16, 631

173 C. B. Sherter and E. J. Mark, N. Engl. J. Med., 2001, 344, 212

174 D. Tejwani, A. E. DeLaCruz, M. Niazi and G. Diaz-Fuentes, J. Med. Case Reports, 2011, 5, 46. 
175 Task Force of the European Society of Cardiology and the North American Society of Pacing and Electrophysiology, Circulation, 1996, 93, 1043.

$176 \mathrm{~J} . \quad$ H. Noseworthy, C. Lucchinetti, M. Rodriguez and B. G. Weinshenker, N. Engl. J. Med., 2000, 343, 938.

177 P. B. Gorelick, Ann. N. Y. Acad. Sci., 2010, 1207, 155.

178 L. Qian, P. M. Flood and J. S. Hong, J. Neural Transm., 2010, 117, 971.

179 S. C. Bondy, Int. J. Environ. Res. Public Health, 2011, 8, 2200.

180 S. Yoshida, M. Sagai, S. Oshio, T. Umeda, T. Ihara, M. Sugamata, I. Sugawara and K. Takeda, Int. J. Androl., 1999, 22, 307.
181 C. Yauk, A. Polyzos, A. Rowan-Carroll, C. M. Somers, R. W. Godschalk, F. J. Van Schooten, M. L. Berndt, I. P. Pogribny, I. Koturbash, A. Williams, G. R. Douglas and O. Kovalchuk, Proc. Natl. Acad. Sci. U. S. A., 2008, 105, 605.

182 E. Carlsen, A. Giwercman, N. Keiding and N. E. Skakkebæk, $B r$. Med. J., 1992, 305, 609 .

183 T. K. Jensen, J. P. Bonde and M. Joffe, Occup. Med., 2006, 56, 544.

184 I. Celardo, J. Z. Pedersen, E. Traversa and L. Ghibelli, Nanoscale, $2011,3,1411$ 